\title{
CSALÁDI EMLÉKEZET ÉS TÖRTÉNELEM
}

DOI: 10.18030/SOCIO.HU.2014.1.81

\section{ABSTRACT}

Based on Annick Percheron's ideas, the memory of key events of family history is supposed to be transmitted from generation to generation and may significantly affect the political socialization of the young generation. A research project on political socialization in the family (2009-2012) has provided an opportunity to test this theory in Hungary. The survey of a national sample of 18 -year-olds and their parents found that more than $50 \%$ of Hungarian families do not keep a live memory of their key events. This article analyses the maintained memory and the factors contributing to the continuity and discontinuity of family memory.

\section{Keywords}

Family's memory, political socialization, historical socialization

\section{ABSZTRAKT}

Annick Percheron nyomán feltételezzük, hogy a családokban nemzedékről nemzedékre átadódnak az átélt történelmi események emlékei, és jelentősen hozzájárulnak az új generáció politikai szocializációjához. A családi politikai szocializáció kutatása (2009-2012) jó alkalmat adott ennek hazai tesztelésére. A magyar 18 évesek és szüleik mintáján folytatott kutatás azt mutatja, hogy a családok több mint felében nem marad fenn a sorsesemények emléke. Részletesen elemezzük azt, ami mégis megmarad, és azokat a tényezőket, amelyek az emlékezet folytonosságához és megszakításához hozzájárulnak.

\section{Kulcsszavak}

Családi emlékezet, politikai szocializáció, történelmi szocializáció 
A családi emlékezet és a történelem kapcsolatának jelen elemzése egy tágabb kutatási projekt részlete. ${ }^{2} \mathrm{~A}$ téma jól meghatározott céllal, a családi politikai szocializáció egyik lehetséges mechanizmusaként került be a kutatásba. ${ }^{3}$ A család tehát a valóság sajátos optikájú és szempontrendszerű társadalmi leképezésével (Berger-Luckmann 1967) járul hozzá a szocializációhoz: megnevez, újraértelmez, értéktulajdonításokat végez, legitimál, szabályoz, mérlegel, bátorít vagy elbátortalanít, instruál, tapasztalatokat összegez, elveket kristályosít ki. A családok különböző mértékben kidolgozott világképeket vagy legalábbis világfelfogásokat alkotnak és örökítenek tovább, s ezek feltehetően legkidolgozottabb része a társadalmi valóság képe. ${ }^{4} \mathrm{~A}$ család a társadalmi élethez szükséges használati utasítások első, érzelmi beágyazottságú, de hierarchikus szerkezetű közvetítője, amelynek hatása későbbi más hatásokra (iskola, kortársak, szervezetek, vallás, eszmék, ideológiák és nem utolsó sorban a további személyes tapasztalatok) módosulhat, de a szocializáció időbeli kontinuitását biztosítja. ${ }^{5}$ A családi szocializáció lényege tehát egyrészt a társadalmi valóság rekonstruálása, másrészt a társadalmi értékek újrafogalmazása és adaptálásuk a családi viszonyokra, harmadrészt a társadalmi valóságban való eligazodás személyes szabályrendszerének („útvonalak”, eszközök, célok, módszerek) megalapozása. A szúkebb értelemben vett családi politikai szocializáció ezen a kereten belül elsősorban az - Almond és Verba (1998) értelmében vett - legáltalánosabban felfogott társadalmi-politikai rendszerhez való viszonyt alakítja. Az eddigi kutatási tapasztalatokon alapuló hipotézisünk szerint ez a legerősebb és legtartósabb - a longuedurée hatások közé illeszkedő hatása. A család számos hatása között azt szerettük volna megtudni, valóban jelentős hatást gyakorol-e a politikai szocializációra az, amit az Annales iskola hosszútávú (longuedurée) hatásnak nevezett, ${ }^{6}$ és amit mi a család sorseseményeinek emlékével próbálunk megközelíteni. Sorseseményeknek a család sorsát is befolyásoló jelentős makrotársadalmi-történelmi eseményeket nevezzük. Kutatásunkkal nem a politikai szocializáció aktuális eredményét, az ifjúság jelenlegi politikai arculatát akartuk megrajzolni, ${ }^{7}$ hanem azoknak a hatásoknak és összefonódásaiknak a feltárásához igyekeztünk hozzájárulni, amelyek és ahogyan ezt az eredményt létrehozzák. ${ }^{8}$

A politikai szocializáció a családban kezdődik, mégpedig nagyon fiatal korban, ám hogyanjáról keveset tudunk. Easton és Hess (1962) tett egy-két anekdotikus megjegyzést Amerikában, Melich (1979) elemezte az értékek átadását Svájcban. A szülők és gyerekeik közötti hatások legrészletesebb elemzését azonban Jennings és Niemi (1981) adta, fiatal felnőttek és szüleik mintáján.

${ }^{2}$ A családi szocializáció című kutatás az OTKA K78759 sz. támogatásával készült, 2009-2011-ben, az összes 12. évfolyamos tanuló

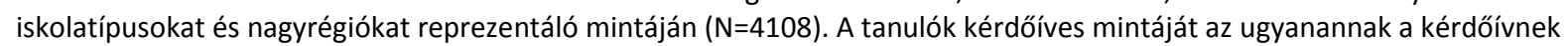
megválaszolására hajlandó szülők önkéntes mintája egészítette ki. Kutatásvezető: Csákó Mihály, vezető kutatók: Szabó Ildikó, Murányi István, Sik Domonkos. A munka különböző szakaszaiban részt vett még: Bognár Adrienn (PTE), Domokos Tamás (ECHO-Survey), Marián Béla (Marketcentrum), Nárai Márta (MTA RKK), Papp Z. Attila (ME). Az adatok a kutatók számára rendelkezésre állnak. A kutatási koncepciót az operacionalizálás részleteivel és a 22 változócsoport gráfjával kutatócsoportunk a Társadalomkutatás c. folyóiratban adta közre (Csákó et al. 2010).

Külön köszönöm kutatótársaim, elsősorban Szabó lldikó és Sik Domonkos e cikkhez nyújtott bíráló és segítő megjegyzéseit.

${ }^{3}$ A fogalmak itt következő tisztázását az 1. lábjegyzetben hivatkozott tanulmányban végeztük el, ahol a változók operacionalizálásáról is részleteket tudhat meg az olvasó. Hangsúlyozom, hogy nem pszichológiai, hanem szociológiai vizsgálatot végeztünk. Az eredményeket természetesen torzíthatja a pszichológiai tényezők nem véletlenszerű szociológiai eloszlása, mivel azonban ennek ellenőrzésére alkalmas kutatásokat eddig nem ismerünk, ezt a tényt lehetőségeink határaként vesszük tudomásul.

${ }^{4}$ D. Reiss (1981) a családi paradigma fogalmát vezeti be azoknak az alapvető előfeltevéseknek az összefoglalására, amelyeket a család tagjai osztanak a társadalmi környezet természetére és a családnak e környezetben elfoglalt helyére vonatkozóan.

${ }^{5}$ Stenley Allen Renshon ezt úgy fogalmazza meg, hogy a családban alakulnak ki azok a „basic belief”-ek, amik minden további kérdésben orientálnak (1975).

${ }^{6}$ Klasszikus írásában Braudel (1958) a napi eseményeket leíró - „krónikás”, „zsurnaliszta” - történettudománnyal szemben a több évtizeden át fennálló struktúrák feltárását tartja igazi történészi feladatnak. Számos példáját bemutatva szembeállítja a szociológia időfogalmával elsősorban Gurvitchra hivatkozva. Kutatásunkban mégis aktuálisnak és megvalósíthatónak tartottunk egy olyan vizsgálódást, amely a braudeli fogalom alapján közelíti meg a mai fiatalokban élő tudati struktúrákat.

${ }^{7}$ A politikai orientáció átörökítésének mértékét vizsgálta Jennings-Percheron (1981).

${ }^{8}$ Technikailag fogalmazva: nem a végső függő változók magyarázatához, hanem a közbülső meghatározók két blokkjának a végső független változócsoportok segítségével történő magyarázatához nyújtunk adalékot (lásd Csákó et al. 2010: 2. ábra). 
Magát a szocializációs folyamatot ők fekete dobozként kezelték, a szülők és gyerekek csoportjának jellemzői közötti egyezéseket kritikus szemmel nézték és az egyes szülő és gyereke közötti egyezésekkel és eltérésekkel ellenőrizték, de az egyezést ezen a szinten már egyértelműen oksági kapcsolatnak, az értékek átadásának tekintették. Pedig ez az értelmezés csak az egyezés hiányára igaz: ha nincs egyezés, akkor biztos, hogy a szülőnek nem sikerült továbbadnia értékeit, attitűdjeit. De ha van egyezés, attól még nem biztos, hogy a gyerek a szülőtől vette át az adott értéket és nem a kosárlabda-edzőjétől.

Bennünket tehát a szocializáció működési mechanizmusai érdekeltek. Ezek közé soroltuk azt a hatást, amelyre Percheron (1999) - és magyar tanítványa, Szabó Ildikó - hívta fel a figyelmet. Feltárásához egy 10 elemből álló sorsesemény-listát készítettünk az utóbbi száz év magyar történelméből. A következő sorsesemények szerepelnek rajta: az I. világháború, a zsidóüldözések, a II. világháború, a kitelepítések és koncepciós perek, a kuláküldözés, az 1956-os forradalom, a disszidálás, a háztájizás és a második gazdaság, a rendszerváltás, és a csatlakozás az Európai Unióhoz. Két kérdést tettünk fel ezekkel kapcsolatban (37. és 38. kérdés). Az első így szólt:

Befolyásolták-e családod életét az alábbi események: az első világháború - Trianon- zsidóüldözés - II. világháború- a kulákok üldözése - kitelepítés, koncepciós perek, államosítás, téeszesítés - az 1956-os forradalom - disszidálás - a „háztáji” gazdálkodás, magánvállalkozások (GMK) engedélyezése - a rendszerváltás, kárpótlás, privatizáció - a csatlakozás az Európai Unióhoz (A lehetséges válaszok minden esetben: befolyásolta / nem befolyásolta / nem tudom.)

A második:

Nagyobb családi összejöveteleken sok családban szóba kerülnek a család történetének fontosabb vagy valami miatt emlékezetes eseményei. Ti szoktatok-e beszélgetni ilyenekről? Témák: az első világháború - Trianon - a zsidóüldözések II. világháború - a kulákok üldözése - a kitelepítés, koncepciós perek, államosítás, téeszesítés - az 1956-os forradalom disszidálás - a „háztáji” gazdálkodás, magánvállalkozások (GMK) engedélyezése - a rendszerváltás, kárpótlás, privatizáció - az őszödi beszéd (A lehetséges válaszok minden esetben: Igen és én is részt veszek a beszélgetésben / Téma, de velem nem beszélnek róla / Téma, de engem nem érdekel / Nem téma a családban.)

\section{A NYERS ADATOK ÁTTEKINTÉSE ${ }^{9}$}

A legmeghökkentőbb adat az, hogy a fiatalok közel fele $(43,9 \%)$ szerint a felsorolt jelentős események ${ }^{10}$ közül egy sem befolyásolta családjukat a XX. század folyamán. Az összes említett esemény számának eloszlása egyébként - mint várható hiperbolikus (1. ábra).

\footnotetext{
${ }^{9}$ Az adatfelvétel az összes középfokú iskola 12. évfolyamos osztályainak olyan országos mintáján történt, amely iskolatípusra és nagyrégiókra is reprezentatív. A mintavételt az ECHO-Survey Szociológiai Kutató Intézet végezte (kutatási igazgató Domokos Tamás).

${ }^{10}$ Az események a kérdőívben nagyjából időrendben voltak felsorolva.
} 
1. ábra

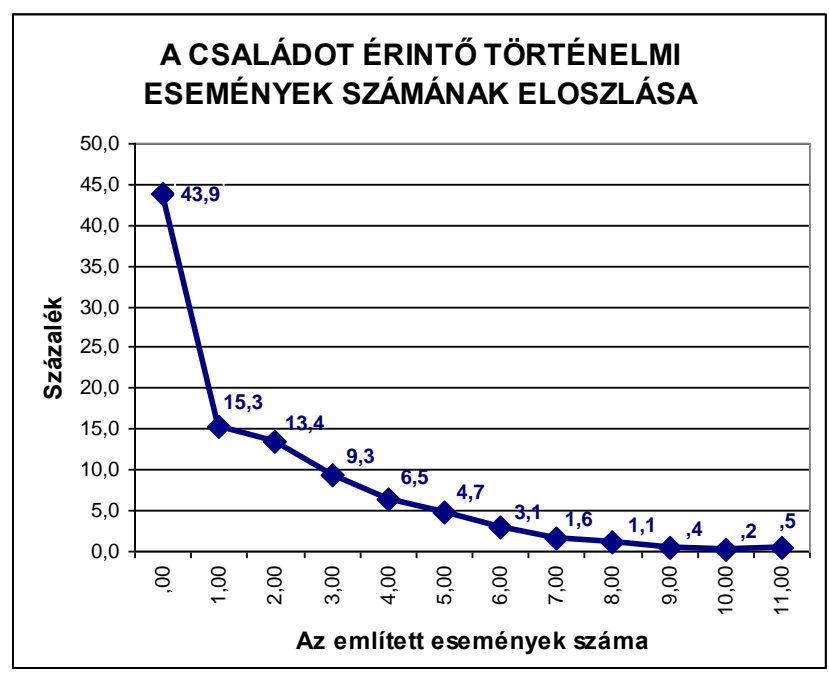

Azt természetesen nem tudjuk megmondani, hogy akik egyetlen esemény hatását sem jelezték, azoknak a családját valóban ennyire kevéssé érintette-e a XX. század történelme (ezt elég nehéz elképzelni), vagy csak a család felserdült gyermeke nem ismeri ezeket a családi történeteket (ami sokkal valószínúbb). Gyanúnkat az is alátámasztja, hogy a megkérdezettek csaknem mindnyájan (92,0\%) megpróbáltak válaszolni, nem hagyták üresen a kérdőívet ezeknél a kérdéseknél.

\section{2. ábra}

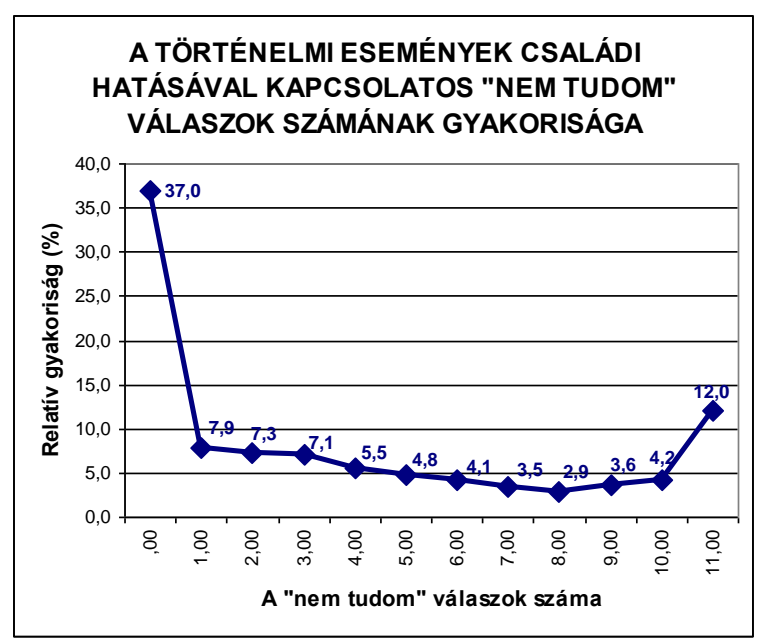

Azok aránya azonban, akik egyszer sem adtak „nem tudom” választ, mindössze 37,0\%, viszont minden nyolcadik fiatal $(12,0 \%)$ az összes felsorolt eseményre így reagált. (A „nem tudom” válaszok eloszlását a 2. ábra mutatja.) Ez azt jelenti, hogy a családok meglehetősen kevéssé járulnak hozzá az emlékezet fenntartásához.

A XX. század néhány fontos történelmi eseménye a 2011-ben 18 éves fiatalok szerint legföljebb a családok 1/3-át érintette. Legkevésbé a holokauszt (3,8\%), a kuláküldözés $(5,2 \%)$ és a disszidálás $(9,3 \%)$ maradt meg a családi emlékezetben. Ez önmagában is eléggé meglepő, mivel a holokauszt a közbeszédben erősen jelen van, a kuláküldözés a rendszerváltás után a kommunista rendszer fő bűnei között kapott helyet, a disszidálás pedig tömegességénél fogva igen kiterjedt rokonságokat érintett. A családi emlékezet sokkal rövidebb: leggyakoribb témája a rendszerváltás: ez a fiatalok szerint a családok 31,9\%-át 
érintette, az Európai Unióhoz való csatlakozás pedig a családok 28,2\%-át. Az utóbbi esemény már a kérdezettek életében, serdülőkoruk kezdetén történt, említése tehát nem annyira a családi emlékezetről, hanem a személyes társadalmi eszmélés kezdeteiről tudósít bennünket. Az a tény, hogy a harmadik „leghatásosabb esemény” a Il. világháború (27,7\%), azt sugallja, hogy bizonyos események az időbeli távolság növekedésével talán összevonódnak egy-egy gyűjtőfogalom alá: így a II. világháború említése is egybegyűjtheti az együtt elszenvedett nehézségeket, egyes családtagok halálát vagy dicsőségét, anyagi veszteségeket és anekdotikus elemeket. Ezzel szemben például az időben hasonló távolságba utaló „zsidóüldözés” hívószó csak a közvetlenül vagy közvetve érintetteket szólítja meg. ${ }^{11}$

A ritkán és a gyakran említett családilag is fontos történelmi események között két közepesen gyakori csoport alakul: a ritkább 10\% körüli, a gyakoribb 15-20\%-os említéssel. A teljes kép a következő (3. ábra):

\section{3.ábra}

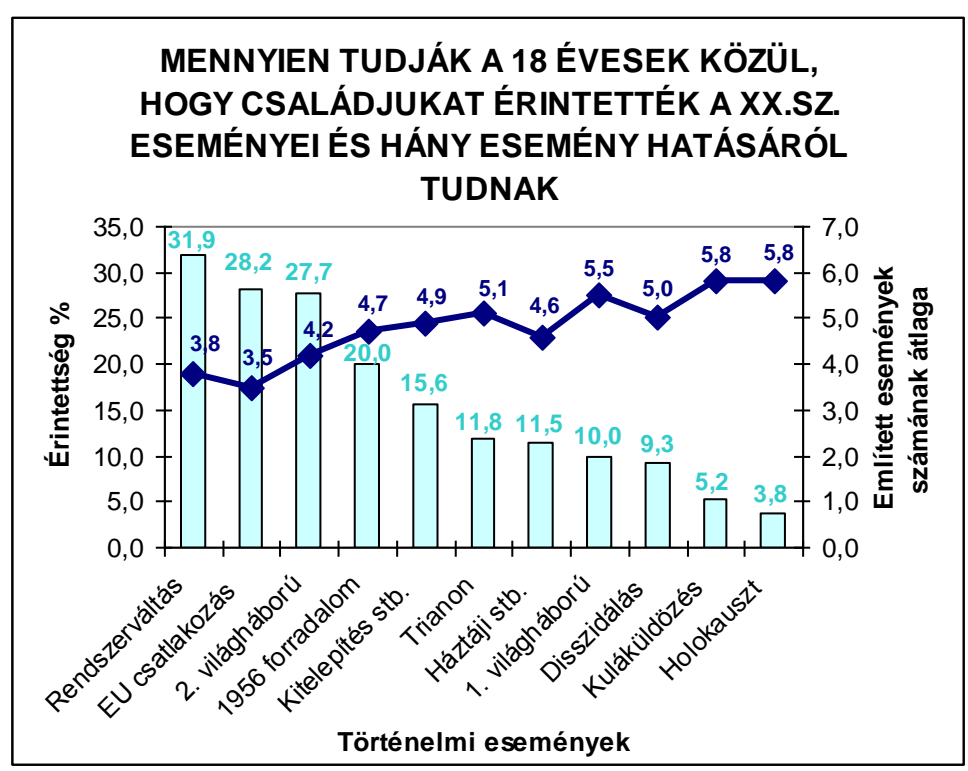

Az ábrán az oszlopok az egyes sorseseményeket említők arányát, a görbe pontjai pedig azt mutatják, hogy azok a fiatalok, akiknek családját érintették az egyes események, összesen hány ilyen családilag fontos eseményről tesznek említést. Már ennyiből is látható, hogy a fiatalok nagyobb része kevesebb eseményt ismer, amely befolyásolta családja történetét, és a kisebb csoportokban - akik a kulákok üldözésére és a holokausztra is emlékeznek - fordul elő, hogy akár 5, sőt 6 másik esemény is eszükbe jut.

\section{A CSALÁDI ÉS A TÁRSADALMI EMLÉKEZET ADATAINAK LOGIKAI SZERKEZETE}

Ha eltekintünk a technikai részletektől és nehézségektől, akkor az összegyűjtött információ logikai szerkezetét három dichotómia alkotja, amelyek közül kettő független egymástól:

${ }^{11}$ Az eredményeket látva valószínűleg helyesebb lett volna a „kulákok üldözése” (5,2\%) és a „kitelepítés, koncepciós perek, államosítás, téeszesítés" (15,6\%) másféle tagolása. Például a kitelepítések és a koncepciós perek mint elsődlegesen politikai megtorló intézkedések elkülönítése az államosítás, kuláküldözés és téeszesítés mint bár ideológiai alapú, de erős gazdasági motívumot tartalmazó intézkedésektől. A válaszok gyakoriságának értelmezése valószínúleg egyszerúbbé vált volna. A mostani eredményeket a leghelyesebb összevonni e két esetben. 
- a család vagy érintett egy esemény által, vagy nem érintett;

- ettől függetlenül a családban vagy téma az adott esemény, vagy nem téma;

- és ha téma, akkor fontos, hogy bevonják-e a gyereket ezekbe a beszélgetésekbe, vagy kihagyják/kizárják belőle.

E logikai viszonyok ábrázolását lásd az 4. ábrán.

4. ábra

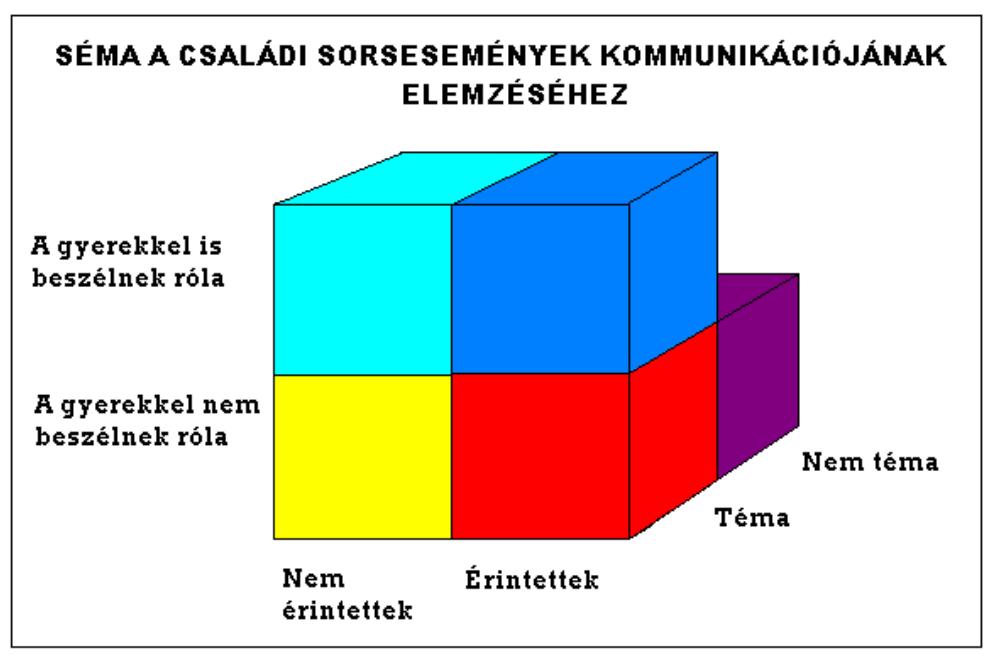

Ábránk három metszete közül egy - az érintettség - nem a családon múlik, nem értelmezés-megítélés tárgya, történelmileg adott. A másik kettő azonban - az, hogy beszélnek-e valamiről, és kivel (a gyerekkel) beszélnek róla - a családon belüli döntés tárgya, még ha nem is tudunk belemenni annak részleteibe, hogyan születik egy ilyen döntés. A számunkra adódó hat értelmezhető kimenetből négy megszakítja a családi történelmi emlékezés fonalát (az ábra alsó rétege), és csak kettő tartja fenn (az ábra felső, hiányos rétege).

Kérdéseink még egy dimenziót bevontak a témába: a gyerek érdeklődését. Ezt az indokolja, hogy a beszélgetésekből való kimaradás ebben az életkorban már nemcsak szülői (felnőtt) döntés lehet, hanem a fiatal saját döntése is. Ez a lehetőség, mely ábránkon nem látható, a történelmi emlékezet megszakításának elkülönülő módja. Természetesen ezt az érdektelenséget is a családon belüli szocializáció eredményének tekintjük, csak ezen a szinten - az egyes események mint témák szintjén - számít önálló tényezőnek. Ebben az elemzésben tehát külön kezeljük. ${ }^{12}$

Első lépésként ennek megfelelően kell átszerkesztenünk adatainkat.

Az I. világháborúra vonatkozó adatokat szerkesztjük át az elemző ábra bemutatásához (5. ábra).

${ }^{12}$ Ez azt is jelenti, hogy csak a séma kockáin kívül szerepeltethetjük. 


\section{5. ábra}

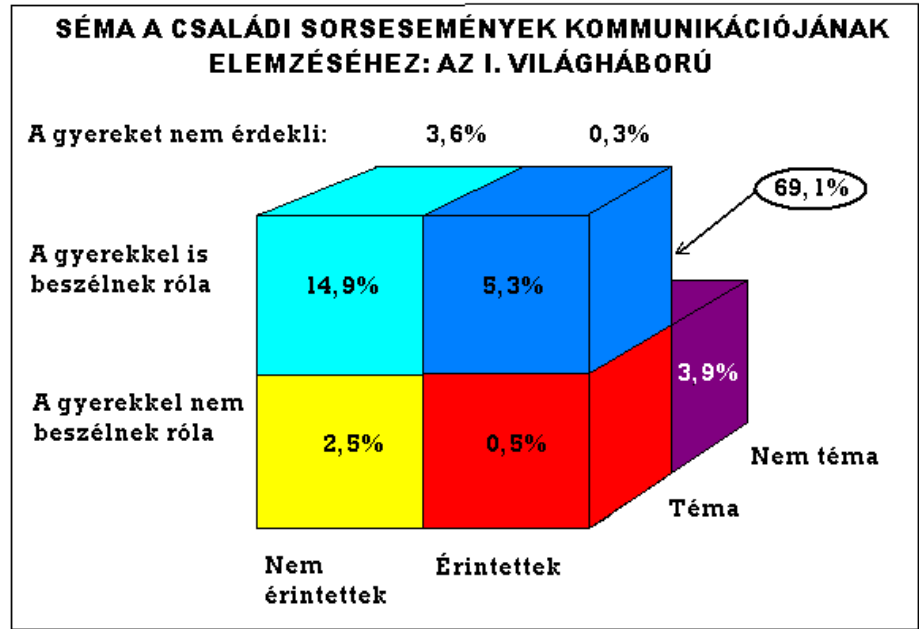

A leggyakrabban előforduló eset kockája a sémában takarásban van: ezek azok a családok, amelyekben a gyerek úgy tudja, hogy az adott esemény nem érinti őket, nem is téma családi beszélgetéseikben, és természetesen a gyerekkel sem beszélnek róla. Bár érthető, hogy valamennyi esemény kapcsán ez a legnagyobb gyakoriságú, valójában triviális eset ${ }^{13}$ (az I. világháborúval kapcsolatban a családoknak több mint kétharmada - lásd a „helyére” mutató nyilat), mégis háttérben hagyjuk. A séma hátsó cellái közül fontosabb láthatóvá tenni azt a korántsem triviális, de ritka esetét a beszélgetések hiányának, amikor a fiatal tudja, hogy a családot érintette a kérdéses esemény, mégsem beszélnek róla (ábránkon 3,9\%). A triviális és a különös ilyen megkülönböztetését az indokolja, hogy ebben az elemzésben nem azt vizsgáljuk, mennyire vannak jelen a családokban azok a témák, amelyeket a közvélemény jelentős része tárgyal, hanem azt, hogy saját sorseseményeik emléke mennyire hagyományozódik generációról generációra a családban. Ha a szülőkben meglévő emlék a generációk közötti kommunikációból bármi okból kiszorul, de még feltételezhető valamilyen hatása, akkor a szocializációs mechanizmusok elemzése során nem az emlékezés kategóriájában, hanem valamilyen más kategória alatt fogjuk számon tartani.

Olyan családtag, aki saját életének eseményeként emlékezhetne az I. világháborúra, nincs a mintánkban, és a teljes népességben is nagyon ritka lehet, hiszen legalább 100 évesnek kell lennie. 2011-ben a 18 év körüli fiataloknak 90 százaléka ${ }^{14}$ nem tud arról, hogy családját érintette volna valahogyan az I. világháború. A többiek 39 százalékában a család megszakította az emlékezés fonalát: nem beszélnek többé arról, hogy mi hogyan történt akkor felmenőikkel. Száz fiatalból hárman maguk szakítják meg az emlékezetet: nem érdekli őket ez a történet; ötüket pedig a szülők rekesztik ki a téma megbeszéléséből, elvágva ezzel a családi történetnek ezt a szálát. De azért az érintett családoknak kicsit több mint a felében (53\%) tovább él az I. világháborús emlékezet. Maga a téma az érintetlen (-nek tudott) családok egy hatodában is tovább él, ezt a társadalmi emlékezet folytatódásának nevezhetjük. ${ }^{15}$

\footnotetext{
${ }^{13}$ Triviális már a nyers adatok ismeretében - egyébként lehetne másként is.

${ }^{14}$ Az 5. ábra adatai alapján: 69,1+2,5+14,9+3,6=90,1\%

${ }^{15}$ Valószínúnek tartom, hogy ezek nagy részében is „érintett” családokról van szó, csak a fiatal számára a beszélgetésekből esetleg nem túnik ki, hogy a család érintettsége miatt fordulnak elő újra meg újra - talán a közvetlen szereplő felmenők kihalása miatt. Ezt a feltevést azonban nem tudjuk alátámasztani, pusztán az I. világháborúban való magyar részvétel mértékére alapozzuk feltevésünket. A személyes, illetve családi vonatkoztatás eltúnése miatt nevezzük ezt az emlékezet-formát társadalmi emlékezetnek.
} 
Nem írom le egyenként a vizsgált sorsesemények sorsát a családokban. Összefoglaló táblázatuk és ábrájuk többet mond, mivel azonnali összehasonlításokat kínál. (1. táblázat - a folytonosság megtartásának csökkenő arányában rendezve)

A táblázat első két oszlopában a válaszoló fiatal maga vállalja fel az emlékezés megszakítójának szerepét („nem érdekli” a téma), a következő négy oszlopban a család a megszakító: a 3. és 4. oszlopban teljesen kizárják a témát - még akkor is, ha a gyerek szerint érintette a családot az esemény -, az 5. és 6. oszlopban a szülők generációjában még él az emlékezet, de a gyereknek - ilyen vagy olyan okból - már nem adják tovább. A jobboldali két oszlop pedig azoknak az arányt mutatja, akikről biztosan állíthatjuk, hogy fenntartják az emlékezet folytonosságát: ${ }^{16}$ a nem érintettek között a társadalmi emlékezet továbbélésének erősségéről ad jelzést, az érintettek között pedig a családi emlékezet megőrzésének erejéről.

1. táblázat: Családi sorsesemények emlékezetének megszakítása és megörzése (\%)

\begin{tabular}{|c|c|c|c|c|c|c|c|c|c|}
\hline \multirow[b]{2}{*}{ Sorsesemények } & \multicolumn{2}{|c|}{ nem érdekli a gyereket } & \multicolumn{2}{|c|}{ nem téma } & \multicolumn{2}{|c|}{$\begin{array}{c}\text { téma, de kizárják a } \\
\text { gyereket }\end{array}$} & \multicolumn{2}{|c|}{$\begin{array}{c}\text { téma, és bevonják a } \\
\text { gyereket }\end{array}$} & \multirow[b]{2}{*}{$\mathrm{N}$} \\
\hline & $\begin{array}{c}\text { nem } \\
\text { érintett } \\
\text { /nem tudja }\end{array}$ & $\begin{array}{c}\text { érintett a } \\
\text { család }\end{array}$ & $\begin{array}{c}\text { nem } \\
\text { érintett } \\
\text { /nem } \\
\text { tudja }\end{array}$ & $\begin{array}{c}\text { érintett a } \\
\text { család }\end{array}$ & $\begin{array}{c}\text { nem } \\
\text { érintett } \\
\text { /nem tudja }\end{array}$ & $\begin{array}{l}\text { érintett a } \\
\text { család }\end{array}$ & $\begin{array}{c}\text { nem } \\
\text { érintettek }\end{array}$ & $\begin{array}{c}\text { érintett a } \\
\text { család }\end{array}$ & \\
\hline II. világháború & 3,5 & 1,1 & 49,9 & 7,6 & 2,5 & 0,9 & 16,4 & 18,0 & 3878 \\
\hline Rendszerváltás & 8,0 & 3,7 & 43,1 & 7,8 & 4,6 & 3,6 & 12,4 & 16,8 & 3860 \\
\hline 1956. forradalom & 4,4 & 1,1 & 57,3 & 5,3 & 3,7 & 1,0 & 14,7 & 12,5 & 3873 \\
\hline Kitelepítések stb. & 4,5 & 1,2 & 69,3 & 5,6 & 3,1 & 1,5 & 7,6 & 7,2 & 3853 \\
\hline Trianon & 3,8 & 0,3 & 66,8 & 3,8 & 3,1 & 0,6 & 14,4 & 7,0 & 3878 \\
\hline I. világháború & 3,6 & 0,3 & 69,1 & 3,9 & 2,5 & 0,5 & 14,9 & 5,3 & 3872 \\
\hline Disszidálás & 4,1 & 0,4 & 77,4 & 2,8 & 2,9 & 0,8 & 6,5 & 5,1 & 3836 \\
\hline Háztájizás stb. & 5,8 & 1,3 & 75,0 & 4,2 & 3,5 & 1,4 & 5,1 & 4,7 & 3837 \\
\hline Kuláküldözés & 4,1 & 0,3 & 84,6 & 1,9 & 2,1 & 0,3 & 4,0 & 2,7 & 3836 \\
\hline Holokauszt & 5,2 & 0,2 & 73,7 & 1,3 & 2,6 & 0,2 & 14,7 & 2,1 & 3867 \\
\hline
\end{tabular}

Azonnal látszik, hogy valóban minden sorseseménnyel kapcsolatban az a csoport a legnagyobb, amely szerint az esemény nincs jelen a családi emlékezetben - vagy nem is érintette a családot, vagy csak a gyerek nem tud róla. Mindössze két olyan sorsesemény volt a XX. században, amelynek emlékezete 2011-ben még a családok több mint feléből nem tűnt el: a II. világháború és a rendszerváltás. Ezek egyúttal valóban a legnagyobb gyakorisággal fenntartott emlékek is, bár a rendszerváltás társadalmi emlékezete máris gyengébb, mint az 1956-os forradalomé (kb. 1/8 az 1/7-hez képest) - aminek leginkább a két esemény óta eltelt idő különbsége (21 ill. 55 év) ad jelentőséget.

${ }^{16}$ Feltételezhető, hogy ennél csak több lehet (sőt, ez valószínű), kevesebb nem. 


\section{6. ábra}

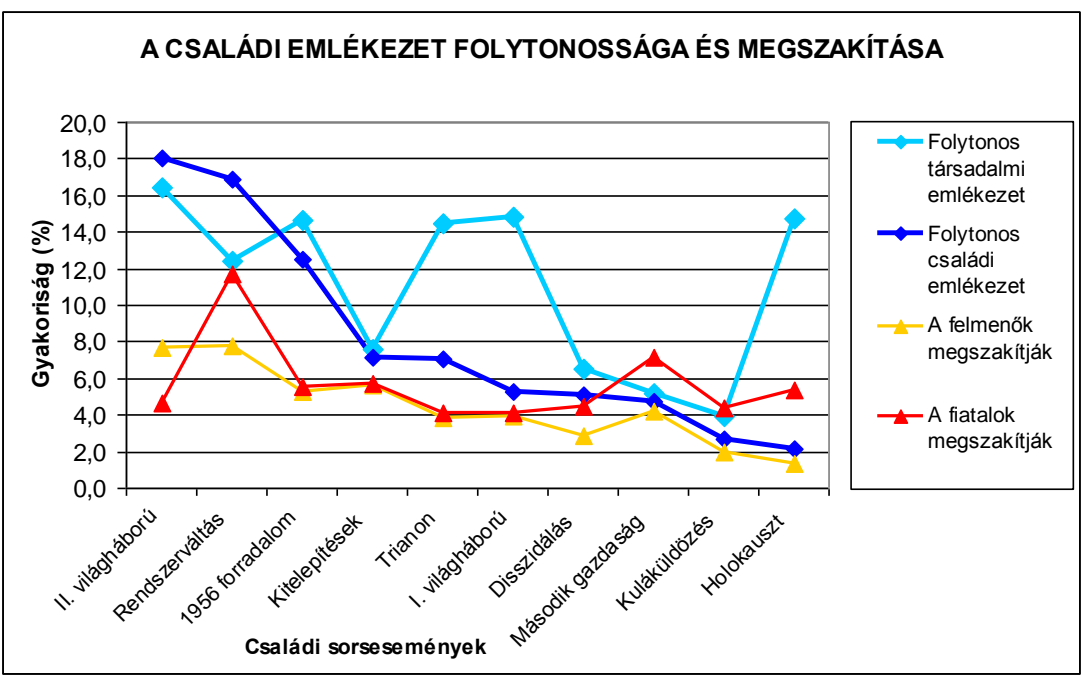

Tanulságos összehasonlítani a folytonosságokat és a megszakítottságokat az egyes sorseseményeknél. (A 6 . ábrán az események a családi emlékezet fenntartásának csökkenő arányában vannak rendezve.)

Feltűnő, hogy három olyan sorsesemény is van, amellyel kapcsolatban a családi emlékezet már meglehetősen ritka, miközben a társadalmi emlékezet fenntartása kifejezetten gyakori a családokban. Ezek: Trianon és az I. világháború, különösen pedig a holokauszt. Trianon társadalmi emlékezete kétszer, az I. világháborúé csaknem ötször, a holokauszté pedig éppen hétszer olyan erős, mint a családi sorshoz kapcsolódó emlékezete. E három eseménnyel nagyjából azonos szintű az 1956-os forradalom és a II. világháború társadalmi emlékezete is, de ezek szorosabban kapcsolódnak a családi emlékezethez, akárcsak az ennél ritkábban előforduló emlékek, amilyen a kitelepítések és politikai perek vagy a kulákok üldözésének emléke. A rendszerváltás az egyetlen olyan sorsesemény, amelynek társadalmi emlékezete már most is sokkal gyengébb, mint családi emlékezete. Mivel pedig a következő generáció kiemelkedő érdektelenséget mutat iránta mind általában (8,0\%), mind pedig a család érintettsége esetén (3,7\%), sorsesemény jellege valószínúleg egy-két évtizeden belül meg fog szűnni, és beleszürkül az állami megemlékezések sorába. ${ }^{17}$

Ezzel együtt a család szerepe egyértelműen kitűnik elemzésünkből. Trianon és a rendszerváltás példáján jól látható, hogy a család szerepe kettős: hordozója a családi emlékezetnek és a társadalmi emlékezetnek is, és e kettő világosan megkülönböztethető. Trianon családi emlékezete meglehetősen gyenge (7,0 \%), igaz, hogy az emlékezet családi megszakításának gyakorisága is kifejezetten gyenge (3,8\%), nemzedéki megszakítása pedig a két legritkábban előforduló magatartás egyike (4,1\%). Trianon társadalmi emlékezetét azonban, ami a közvetlenül nem érintett - vagy az érintettség emlékét már nem őrző - családok kommunikációjában mutatkozik meg, a családok 14 százaléka fenntartja, ami a legnagyobb gyakoriságok egyike. ${ }^{18} \mathrm{Ez}$ azt jelenti: korántsem biztos, hogy szoros kapcsolat van a családok családi emlékezete és a beszélgetéseikben fenntartott társadalmi emlékezet között, bár az továbbra is biztosra vehető, hogy van ilyen kapcsolat. Ez a

\footnotetext{
${ }^{17}$ E formában való megmaradását elősegíti a fordulónap - október 23. - összekötése 1956 emlékével.

${ }^{18}$ Három sorsesemény fordul elő $14 \%$ és $15 \%$ közötti relatív gyakorisággal a családok között: az I. világháború, az 56-os forradalom és Trianon és ezeknél csak a Il. világháború gyakoribb téma (16,4\%) az adott esemény által „érintetlen” családokban.
} 
kutatás nem mehet mélyebbre e kapcsolat feltárásában, de eredménye mutatja, hogy családszociológiai vizsgálatoknak érdemes e családon belüli emlékezési mechanizmusokat tovább kutatniuk.

\section{A LÁTENS STRUKTÚRA}

Mindenképpen megállapítható, hogy van egy jelentős része a középkorú magyar népességnek, amelyben a történelmi emlékezet családi szála megszakad, és gyerekeikben nem élnek tovább azok az emlékek, amelyeket szüleik, nagyszüleik életük során gyűjtöttek. (E csoport körülhatárolására még visszatérünk.) Eredetileg azt vártuk, hogy a különböző családok emlékeiből egyfajta mintázat alakul ki: egyes családok bizonyos sorsesemények emlékét őrzik, mások pedig másokét. Még azt is elképzelhetőnek tartottuk, hogy az eltérő emlékegyütteseket őrző családok más társadalmi és/vagy kulturális jellemzőikben is jellemzően eltérnek egymástól.

Adatainkból azonban az derült ki, hogy csak kétféle családi emlékezést találunk. Az egyikben a régi események dominálnak, az I. világháborútól a disszidálásig, a másikban feltűnik az utóbbi húsz év emlékezete is. Tehát az emlékezés rejtett struktúráit keresve a következő képet kapjuk (2. táblázat):

\section{2. táblázat: A családi emlékezet két összetevője}

\begin{tabular}{|l|c|c|}
\hline \multirow{2}{*}{ Érintette a családot } & \multicolumn{2}{|c|}{ Komponens } \\
\cline { 2 - 3 } & 1 & 2 \\
\hline A kulákok üldözése & $\mathbf{, 7 4 3}$ &,- 061 \\
Az I. Világháború & $\mathbf{7 2 1}$ &,- 215 \\
A disszidálás & $\mathbf{6 1 2}$ &,- 243 \\
Az EU-csatlakozás &, 125 &,- 850 \\
A rendszerváltás &, 307 &,- 818 \\
\hline
\end{tabular}

ExtractionMethod: PrincipalComponentAnalysis.

RotationMethod: Obliminwith Kaiser Normalization.

Vajon ezeknek az emlékezés-típusoknak a kombinációi kijelölnek-e sajátos csoportokat a családok között? Ha klaszterelemzéssel keressük az emlékezési módokat hordozó csoportokat, három klasztert tudunk jól értelmezni, ezek középpontjai jól eltérnek egymástól (más-más síknegyedbe esnek: 7. ábra), az elemek szóródása a középpontok körül különböző mértékű, és egyéb tulajdonságaik különbségei is értelmezhetők. 


\section{7. ábra}

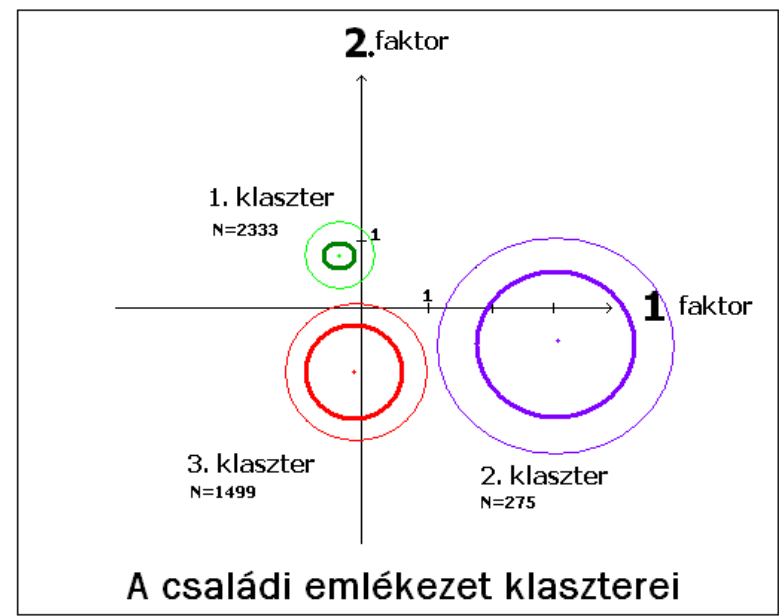

Jelmagyarázat: A pontok a klaszterközéppontokat jelölik; a vastag körök a klaszterek elemeinek átlagos távolságát, a vékony körök pedig 1 szórásegységgel nagyobb sugarúak az átlagnál.

Az adatok részleteit a 3 . táblázat mutatja.

3. táblázat: A családok történelmi érintettsége klasztereinek jellemzői

\begin{tabular}{|c|c|c|c|c|c|c|c|c|}
\hline $\begin{array}{l}\text { Történelmi érintettség } \\
\text { klaszterek }\end{array}$ & \multicolumn{2}{|c|}{$\begin{array}{l}\text { Klaszterközepek } \\
\text { koordinátái }\end{array}$} & $\mathrm{N}$ & $\begin{array}{l}\text { Átlagos } \\
\text { távolság } \\
\text { a } \\
\text { középtől }\end{array}$ & $\begin{array}{c}\text { A } \\
\text { klaszterközéptől } \\
\text { való távolság } \\
\text { szórása }\end{array}$ & $\begin{array}{c}\text { Hány } \\
\text { eseményt } \\
\text { említenek } \\
\text { átlagosan, ami } \\
\text { érintette a } \\
\text { családot? }\end{array}$ & $\begin{array}{l}\text { Az apa } \\
\text { átlagos } \\
\text { életkora }\end{array}$ & $\begin{array}{l}\text { Az anya } \\
\text { átlagos } \\
\text { életkora }\end{array}$ \\
\hline & $\begin{array}{l}\text { 1.faktor: } \\
\text { hosszútávú }\end{array}$ & $\begin{array}{l}\text { 2.faktor: } \\
\text { rövidtávú }\end{array}$ & & & & $p<0,000$ & $p<0,000$ & $p<0,000$ \\
\hline alig emlékező családok & $-0,3091$ & 0,7479 & 2333 & 0,1991 & 0,3375 & 0,4149 & 46,71 & 43,72 \\
\hline $\begin{array}{l}\text { hosszan emlékező } \\
\text { családok }\end{array}$ & 3,0833 & $-0,4816$ & 275 & 1,4482 & 0,5561 & 5,8866 & 48,22 & 45,20 \\
\hline $\begin{array}{l}\text { rövid távon emlékező } \\
\text { családok }\end{array}$ & $-0,0844$ & $-1,0750$ & 1499 & 0,8584 & 0,3055 & 2,8954 & 47,71 & 44,63 \\
\hline
\end{tabular}

Megdöbbentően kevés olyan család van, ahol igazi családi-történeti emlékezetről beszélhetünk. A legnagyobb csoportot (ábránkon a legkisebb, mert legtömörebb kört) azok a fiatalok alkotják, akik alig egy-két eseményt tudnak családjukkal kapcsolatba hozni, és számuknak alig több, mint egy tizedét teszik ki azok, ahol részletesebb, sok eseményhez kapcsolódó családi történet maradt fenn (ez a legnagyobb, mert legszórtabb, azaz legváltozatosabb kör). Egy bő harmadrésznyi csoportban csak a szülők életének közelmúltban átélt változásai, eseményei hagytak nyomot, némi reménnyel arra, hogy majd a következő generáció számára továbbörökítendő emlékké válnak. Értelmezésünket különösen jól alátámasztja az egyes klaszterek tagjai által említett sorsesemények átlagos száma (a táblázat jobbról 3. oszlopában).

A családi emlékezetre vonatkozó adataink látens struktúrája egyértelműen arra utal, hogy a magyar családok nagy részében nem élő múlt a család huszadik századi története, ez még a 18 évesek családjainak 7 százalékára sem jellemző. A 
történelem emlékszálai elmosódtak, és ha egyes események emléke mégis élénk, akkor abban már jelentős családon kívüli, másodlagos hatásokat is fel kell tételeznünk.

\section{A CSALÁDI EMLÉKEZET TÁRGYI VILÁGA}

Feltételeztük, hogy a régi élmények, csapások, örömök nemcsak a verbális családi emlékezetben őrződnek, hanem a családi „emlékeztetőkben” is: a szimbolikus tárgyakban, amelyekkel a család körülveszi magát. ${ }^{19}$ Azt a hasonlóságot és különbözőséget, amelyet a szülői lakásban található díszek és a gyerekek szobáiban - mint önálló felügyeletük alatt álló térben található díszek, relikviák között megfigyelhetünk, szintén értelmezhetjük egyúttal tárgyi emlékezetként, az emlékezet folytatódásának, illetve módosulásának, vagy éppen megszakadásának jeleként.

A fiatalok által preferált szobadíszek-relikviák nem mutatnak éles mögöttes struktúrát, faktorok keresése itt zátonyra fut. A főkomponens elemzés azonban halványan három tendenciát jelez. Az első és leghatározottabb a nemzeti-politikai jelképek preferálása, amely kötődhet a vallásosság jeleihez, de önállóan is létezik. A másodikban éppen a vallásosság hangsúlyos, mégpedig a politika teljes kizárásával, legföljebb a világi szórakozás jelképeivel társul. A harmadikat akár „kozmopolitának” is címkézhetnénk: a vallás kimarad, a szórakozás jelei mellett a politikai jelek tűnnek fel másodikként. (4. táblázat) E három komponens azonban nem különül el élesen, mint a táblázat is mutatja, átfedik egymást

4. táblázat: A fiatalok szobájában található díszek fökomponens-elemzése

\begin{tabular}{|l|l|l|l|}
\hline \multirow{2}{*}{} & \multicolumn{2}{l}{ Komponens } & \multicolumn{2}{l|}{3} \\
\cline { 2 - 4 } & 1 & 2 & $-1,140$ \\
\hline Magyar zászló &, 631 &,- 159 &,- 197 \\
\hline Politikai jelkép &, 620 &,- 420 &, 197 \\
\hline A történelmi Nagy-Magyarország térképe &, 595 &,- 098 &,- 383 \\
\hline Történelmi emlék, ereklye &, 542 &, 120 &,- 303 \\
\hline Kép/fénykép politikus(ok)ról &, 481 &,- 452 &, 381 \\
\hline Más nemzet zászlaja &, 410 &, 157 &, 304 \\
\hline Valamilyen szöveg (idézet, ima, mondás stb.) &, 426 &, 533 &, 066 \\
\hline Valamilyen vallási jelkép (szentkép, kereszt, menóra, Buddha stb.) &, 380 &, 510 &,- 260 \\
\hline Mai ismert személy (celeb) posztere (énekes, sportoló, színész, stb.) &, 193 &, 446 &, 628 \\
\hline ExtractionMethod: PrincipalComponentAnalysis. & & & \\
\hline
\end{tabular}

A lakás többi részében ugyanezek a tendenciák még egy kicsit gyengébben érvényesülnek. A fiatalok territóriumán túl lévő részekben természetesen ritkák a sztárok és celebek poszterei, ezért a főkomponens-elemzés nem három, hanem csak két komponenst tud megkülönböztetni.

${ }^{19}$ Kérdéseink (18. és 19. kérdés) ezek voltak:

- Van-e a szobádban kitéve a falra vagy polcra, bárhova: valamilyen vallási jelkép (szentkép, kereszt, menóra, Buddha stb.) / a történelmi NagyMagyarország térképe / magyar zászló / más nemzet zászlaja / politikai jelkép / kép, fénykép politikus(ok)ról / történelmi emlék, ereklye / mai ismert személy (celeb) posztere (énekes, sportoló, színész, stb.) / valamilyen szöveg (idézet, ima, mondás stb.) / Nincs külön szobám (Tégy X-et abba a sorba, ami van!)

- És a lakás más részében van ilyen? (a felsorolás és az utasítás azonos). 
5. táblázat: A lakásban található díszek fökomponens-elemzése

\begin{tabular}{|l|l|l|}
\hline & \multicolumn{2}{l|}{ Component } \\
\cline { 2 - 3 } & 1 & 2 \\
\hline Kép/fénykép politikus(ok)ról &, 796 &, 184 \\
Más nemzet zászlaja &, 796 &, 220 \\
Politikai jelkép &, 786 &, 249 \\
Magyar zászló & 635 &, 475 \\
Mai îsmert személy (celeb) posztere (énekes, sportoló, színész, stb.) &, 338 &, 284 \\
Valamilyen vallási jelkép (szentkép, kereszt, menóra, Buddha stb.) &, 139 &, 696 \\
Valamilyen szöveg (idézet, ima, mondás stb.) &, 225 &, 676 \\
Történelmi emlék, ereklye &, 339 &, 642 \\
A történelmi Nagy-Magyarország térképe &, 522 &, 530 \\
\hline
\end{tabular}

ExtractionMethod: PrincipalComponentAnalysis.

RotationMethod: Obliminwith Kaiser Normalization.

Ha nem felejtjük el, hogy mind a saját szobájukról, mind a lakás egészéről a fiatalok adtak képet, a hasonlóság mértékéből - amely jelentős a két tér között - arra következtethetünk, hogy a gyerek-generáció nem teljesen másnak, inkább csak kicsit határozottabbnak és persze divatosabbnak látja magát szüleinél a maga tartotta tükörben. A szülők terében is a vallás és a politika különbsége differenciálja az attitűdök alapjait, a kapcsolódási pontot pedig a nemzeti érzés nyújtja. A múlt, a hagyomány a szülői térben erősebben kapcsolódik a vallással, mint a fiatalokéban, ahol inkább elválnak egymástól, és a történelem a politika szolgálatába áll. ${ }^{20}$

Vajon a történelemhez való kötődésben mekkora szerepük van a családi sorseseményeknek, és befolyásolja-e a szerepüket a szülők és gyerekek közötti folytonosság vagy annak hiánya?

Ha az egyes tendenciákat jelző szimbolikus díszítésekből átlagot képzünk, kiderül, hogy míg a szülői térben a vallásitörténelmi elemek jellemzők inkább, addig a fiatalok rendelkezésére álló térben inkább a nemzeti-politikai elemek. A családon belüli folytonosság azonban itt is kitűnik (6. táblázat).

6. táblázat: $A$ szülök és a gyerekek által felügyelt terek díszitésének korrelációja ( $N=4108)$

\begin{tabular}{|l|c|c|}
\hline $\begin{array}{l}\text { A } \begin{array}{l}\text { SZÜLŐI } \\
\text { HELYISÉGEK }\end{array} \\
\text { TERE: }\end{array}$ & $\begin{array}{c}\text { NEMZETI-POLITIKAI } \\
\text { JELKÉP A } \\
\text { SZOBÁBAN } \\
\text { (átlagpont) }\end{array}$ & $\begin{array}{c}\text { VALLÁSI JELKÉP } \\
\text { A SZOBÁBAN } \\
\text { (átlagpont) }\end{array}$ \\
\hline POLITIKAI JELKÉP A LAKÁSBAN (átlagpont) &, $209^{* *}$ &, $154^{* *}$ \\
\hline $\begin{array}{l}\text { VALLÁSI-TÖRTÉNELMI JELKÉP A LAKÁSBAN } \\
\text { (átlagpont) }\end{array}$ &, $232^{* *}$ &, $326^{* *}$ \\
\hline$* * \mathrm{p}<0,00$ & & \\
\hline
\end{tabular}

\footnotetext{
${ }^{20}$ Mérni természetesen csak a kapcsolatot tudjuk, ez a megfogalmazás külön véleményt tesz hozzá az adathoz, amit az adat csak megenged, de nem támaszt alá pozitívan.
} 
A korrelációk azt mutatják, hogy a vallás a legerősebb hosszú távon átívelő kapocs a generációk között. Ez nemcsak abban fejeződik ki, hogy ha a szülők kedvelik a vallási jelképeket, akkor a gyerekek is hajlamosabbak erre ( $r=0,326$ - ez a legerősebb kapcsolat a táblázatban), hanem abban is, hogy a fiatalok nemzeti-politikai attitűdjét kifejező díszítések sem a szülői lakás politikai díszeivel korrelálnak erősebben $(r=0,209)$, hanem a vallási-történelmi jellegúekkel $(r=0,232)$. Ez egyúttal azt is megerősíti, hogy a politikusabb fiatalok nagyobb mértékben „örökösei” a vallásos nemzeti történelemhez kötődő szülőknek, és csak kisebb mértékben a valláshoz nem kötődő, ám politizáló hagyománynak, amelytől azonban a nemzeti érzés - mint már láttuk - nem idegen.

Maguk a fiatalok arra vezetnek tehát rá, hogy erősen emocionális attitűdjeikben a politika szüleik vallásos és nemzeti érzelmeinek leszármazottja, miközben a nemzeti elem vallási-történelmi jellegűből vallástalan-politikaivá transzformálódik. Mindennek pedig egyik erős gyökere a család sorseseményeiben rejlik. Bár ezeket eddig nem tudtuk eléggé specifikálni a válaszok alacsony száma miatt, annyi bizonyos, hogy a hosszabb múltat felidéző családok használnak több történelmi szimbólumot díszítésre, és rájuk sokkal inkább jellemző a kimutatott mechanizmus, mint a rövidtávú emlékezettel - vagy semmilyennel - nem bíró családokra.

Az emlékezet klaszterei szignifikánsan eltérő díszítési tendenciákat mutatnak (7. táblázat).

Az eddigiek után az már nem meglepő, hogy a vallási kötődést a követlen tárgyi környezet szimbólumai mindkét generációban erősebbnek mutatják minden másnál. Az azonban feltűnő, hogy a legerősebb kapcsolatot a családi emlékezet és az emocionálisan hangsúlyos irányultságot kifejező szimbólumok között a fiatalok politikai jelképekhez való kötődésében találjuk: míg a szülőknél a hosszú távú emlékezet csupán eta=0,039 erősségű kapcsolatban van a politikai jelképek közszemlére tételével, addig gyerekeiknél ez a kapcsolat eta=0,172 erősségű.

7. táblázat: Díszítési tendenciák a szülöknél és a gyerekeknél a történelmi érintettség klasztereiben (átlagpontszámok, varianciaelemzés)

\begin{tabular}{|l|c|c|c|c|}
\hline Történelmi érintettség klaszterek & $\begin{array}{c}\text { POLITIKAI JELKÉP } \\
\text { A LAKÁSBAN } \\
\text { (átlagpont) }\end{array}$ & $\begin{array}{c}\text { VALLÁSI- } \\
\text { TÖRTÉNELMI } \\
\text { JELKÉP A } \\
\text { LAKÁSBAN } \\
\text { (átlagpont) }\end{array}$ & $\begin{array}{c}\text { NEMZETI- } \\
\text { POLITIKAI JELKÉP } \\
\text { A SZOBÁBAN } \\
\text { (átlagpont) }\end{array}$ & $\begin{array}{c}\text { VALLÁSI } \\
\text { JELKÉP A } \\
\text { SZOBÁBAN } \\
\text { (átlagpont) }\end{array}$ \\
\hline alig emlékező családok &, 0683 &, 1864 &, 0577 &, 1919 \\
\hline hosszan emlékezó családok &, 0919 &, 2736 &, 1567 &, 3087 \\
\hline rövid távon emlékező családok &, 0781 &, 2381 &, 0809 &, 2402 \\
\hline df & 2 & 2 & 2 & 2 \\
\hline$F$ & 3,203 & 26,199 & 62,797 & 22,696 \\
\hline$p$ & 0,041 & 0,000 & 0,000 & 0,000 \\
\hline eta & 0,039 & 0,112 & 0,172 & 0,105 \\
\hline
\end{tabular}

\section{Megállapíthatjuk tehát, hogy}

- bár a legerősebb átöröklődő elem a vallási kötődés, az is sokkal erősebben hagyományozódik a hosszú távú emlékezetet ápoló családokban, mint az emlékezet nélküli vagy rövid távú emlékezettel bíró családokban; 
- a politikai irányultságot is csak a hosszabb távú családi emlékezet segíti kialakulni;

- ezt a folyamatot a nemzeti identitás katalizálja, de úgy, hogy vallási-történelmi - azaz elsődlegesen kulturális - elemből a fiatal nemzedékben elsődlegesen politikai jelentésűvé válik.

Természetesen nem felejtjük el, hogy határozott hatásokat azonosító megállapításaink nagyjából minden tizenötödik fiatal családjára vonatkoznak csak, ezzel szemben tízből hat fiatalt nem érnek ilyen hatások a családban. Ennek tudatában vizsgáljuk meg azokat a tényezőket, amelyek e mechanizmust befolyásolhatják, működését, eredményét differenciálhatják.

\section{A CSALÁDI EMLÉKEZETET BEFOLYÁSOLÓ TÉNYEZŐK: CSALÁDSTRUKTÚRA}

A 3. táblázat már tartalmaz két olyan adatot, amely a mögöttes tényezőkről szól. Triviális arra gondolni, hogy a szülők életkora befolyásolja mind azt, hogy mit éltek át, mind azt, hogy milyen közvetett örökséget kaphattak, mind pedig azt, hogy mennyire alakítottak ki saját maguk családi emlékezési formákat, és ezek segítségével mennyire adták tovább gyerekeiknek a maguk emlékezet-örökségét. E sok triviálisnak látszó funkcióhoz képest a szülők életkora igen kevéssé - bár szignifikánsan befolyásolja a gyerekeikben élő családi emlékezetet. ${ }^{21}$ Gondolhatnánk, hogy egyetlen középiskolás évfolyamból véve mintánkat, talán túl szűk idősávban szóródik a szülők életkora, de nem ez a helyzet. Az interkvartilis távolság az apáknál 7, az anyáknál 11 év - tehát előfordulhatna, hogy bizonyos emlékeket csak az 50 évesnél idősebb szülők őrizzenek és adjanak tovább, a 43 évesnél fiatalabbak pedig ne. Ilyen szélsőséges eloszlás azonban nem látszik, sőt, az apák életkorának szórása mindhárom klaszterben 5 év fölött van, ami azt jelenti, hogy valamelyes hatása ugyan kimutatható, ám a szülők életkora mégsem döntő tényező a családi emlékezetben. ${ }^{22}$

Szintén kézenfekvő feltevés, hogy az emlékezet összefügg a család összetételével, hiszen az összetétel maga is a családtörténet egyik eredménye. Tudjuk, hogy a 18 éves fiatalok családjainak 72\%-ában jelen van az édesapa és az édesanya is.

Joggal várjuk, hogy a hosszabb távú emlékezettel rendelkező családokban a nagyszülők jelenlétének köszönhető e sajátosság fennmaradása. Kétségtelen, hogy az emlékezetklaszterek és a nagyszülők jelenléte között szignifikáns kapcsolat van ( $p=0,019)$, ami főleg annak köszönhető, hogy a hosszú távon emlékező családoknak a várható 20,4\% helyett 27,6 százalékában van két nagyszülő, ezzel szemben a várható $56,0 \%$ helyett csak 48,7 százalékukban nincs sem nagyapa, sem nagyanya. Az is látható azonban, hogy a százalékszámok nagyságához képest a különbségek viszonylag kicsik, így nem lep meg bennünket, hogy ez a kétségtelenül fennálló kapcsolat gyenge (Cramer V=0,043). Ez azt jelenti, hogy a nagyszülőknek - ha jelen vannak a családban - pozitív szerepük van ugyan a családi emlékezet hosszú távú fenntartásában, de nem valószínú, hogy a családi kommunikáció erős tényezői lennének. Egy erre irányuló intenzív, kvantitatív módszereket alkalmazó kutatás számára azt a hipotézist javasolhatnánk, hogy a családi emlékezet nem a jelenlegi szülök generációjában kezdett erodálódni, hanem már a jelenlegi nagyszülök generációjában - ha nem még korábban.

\footnotetext{
${ }^{21}$ Magyarázó ereje az 1\%-ot is alig éri el. Az apák esetében eta ${ }^{2}=0,009 ;$ az anyáknál eta ${ }^{2}=0,010$. EZ AZÉRT NÉGYZET, MERT NEM A KAPCSOLAT ERŐSSÉGÉT, HANEM A MEGMAGYARÁZOTT VARIANCIÁT JELÖLI.

${ }^{22}$ Legalábbis ebben a középkorú népességben. Messze vezető sejtés lehet, hogy esetleg a történelmi-társadalmi környezet homogenizáló hatása érvényesült a különböző életkorú, de hasonló korú gyermekkel rendelkező szülőkre.
} 
Ugyanakkor azt, hogy a nagyszülők hatásos szereplői a szocializációs folyamatnak, az a tény is alátámasztja, hogy a rövid távú családi emlékezet gyakoriságában is hasonló irányú, csak még sokkal gyengébb eltéréseket okoz a jelenlétük.

Ez a gyenge hatás az egyes sorseseményeket külön-külön vizsgálva is látható. Már abban is megmutatkozik, hogy hányat tudnak közülük felidézni azok a fiatalok, akik rendszeresen találkoznak nagyszülővel, és hányat azok, akik nem (8. táblázat).

\section{8. táblázat: A nagyszülök jelenlétének hatása a családi emlékezet továbbörökítésére}

\begin{tabular}{|l|c|c|c|c|c|}
\hline \multirow{2}{*}{$\begin{array}{l}\text { A NAGY-SZÜLŐK } \\
\text { JELENLÉTE }\end{array}$} & \multicolumn{2}{|c|}{$\begin{array}{c}\text { HÁNY TÖRTÉNELMI } \\
\text { ESEMÉNY HATÁSÁT } \\
\text { EMLÍTI? }\end{array}$} & \multicolumn{2}{|c|}{$\begin{array}{c}\text { HÁNY ESEMÉNYRÖL } \\
\text { NEM TUDJA, HOGY } \\
\text { HATOTT-E? }\end{array}$} & \multirow{2}{*}{$\mathrm{N}$} \\
\cline { 2 - 5 } & Átlag & Szórás & Átlag & Szórás & \\
\hline Nincs nagyszülő & 1,57 & 2,09 & 3,89 & 4,14 & 2301 \\
\hline Csak nagyanya & 1,78 & 2,15 & 3,71 & 3,98 & 858 \\
\hline Csak nagyapa & 1,88 & 2,30 & 3,25 & 3,69 & 111 \\
\hline Mindkettő & 1,87 & 2,23 & 3,18 & 3,69 & 838 \\
\hline Együtt & 1,69 & 2,14 & 3,69 & 4,03 & 4108 \\
\hline
\end{tabular}

Egyértelmű, hogy ahol nincs nagyszülő, ott gyengébb a családi emlékezet, mint ott, ahol van. Felmerülhet azonban, hogy talán nem mindegy, milyen eseményekről van szó; elképzelhető, hogy bizonyos eseményekre - például a régebbiekre - csak akkor emlékeznek igazán, ha egy nagyszülő személyes jelenléte segít fenntartani az emlékezetet. Példának vegyük Trianont, a holokausztot, a II. világháborút és a rendszerváltást (9. táblázat). Ezekben az esetekben továbbra is igaz, hogy többnyire erősebb a családi emlékezet, ha a nagyszülők jelen vannak, mint ha nincsenek, ám a többi sorseseménnyel, a disszidálásokkal és a háztájizással, a második gazdaság jelenségeivel kapcsolatban nincs szignifikáns hatásuk.

9. táblázat: Nagyszülők jelenlétének hatása a családi emlékezet folytonosságára

Trianon
\begin{tabular}{|l|c|c|c|}
\hline \multirow{2}{*}{$\begin{array}{l}\text { Nagyszülő } \\
\text { a családban }\end{array}$} & A fiatalok & A szülők & \multirow{2}{*}{$\begin{array}{c}\text { Folytonos } \\
\text { emlékezet }\end{array}$} \\
\cline { 2 - 3 } Nincs & \multicolumn{2}{|c|}{ megszakítják* } & CrV=0,054 \\
\hline Kettő van & 4,6 & 72,1 & 19,9 \\
\hline
\end{tabular}

Holokauszt
\begin{tabular}{|l|c|c|c|}
\hline $\begin{array}{l}\text { Nagyszülő } \\
\text { a családban }\end{array}$ & A fiatalok & A szülők & \multirow{2}{*}{$\begin{array}{c}\text { Folytonos } \\
\text { emlékezet }\end{array}$} \\
\cline { 2 - 3 } & \multicolumn{2}{|c|}{ megszakítják } & 0,052 \\
\hline Nincs & 5,9 & 75,9 & 15,5 \\
\hline Kettő van & 4,2 & 72,6 & 20,4 \\
\hline
\end{tabular}

II. világháború

\begin{tabular}{|l|c|c|c|}
\hline \multirow{2}{*}{$\begin{array}{l}\text { Nagyszülő } \\
\text { a családban }\end{array}$} & A fiatalok & A szülók & $\begin{array}{c}\text { Folytonos } \\
\text { emlékezet }\end{array}$ \\
\cline { 2 - 3 } & \multicolumn{2}{|c|}{ megszakítják } & 20,5 \\
\hline Nincs & 5,0 & 61,5 & 42,5 \\
\hline Kettő van & 4,5 & 50,3 & CrV=0,058 \\
\hline \multicolumn{3}{|c|}{$96=0,011$} \\
\end{tabular}




\begin{tabular}{|l|c|c|c|}
\hline \multirow{2}{*}{$\begin{array}{l}\text { Nagyszülő } \\
\text { a családban }\end{array}$} & A fiatalok & A szülők & \multirow{2}{*}{$\begin{array}{c}\text { Folytonos } \\
\text { emlékezet }\end{array}$} \\
\cline { 2 - 3 } & \multicolumn{2}{|c|}{ megszakítják } & 17,3 \\
\hline Nincs & 10,5 & 54,5 & 33,7 \\
\hline Kettő van & 14,0 & 44,1 & \\
\hline
\end{tabular}

* Megszakítják az emlékezetet: a gyereket nem érdekli; a szülők nem beszélnek róla.

Azok a sorsesemények, amelyekkel kapcsolatban a nagyszülőknek emlékezet-fenntartó szerepük van, a rendszerváltás kivételével valóban a XX. század korábbi évtizedeiből valók. Ez azonban nem jelenti azt, hogy saját aktív életük sorseseményeivel kapcsolatban lennének hatásosak, az újabbakkal kapcsolatban pedig nem. Az I. világháború és a trianoni diktátum idején még a nagyszülei közül is kevesen éltek a jelenlegi 18 éveseknek, a zsidóüldözések és a II. világháború idején pedig nagy részük gyerek volt. Azt látjuk tehát, hogy amit továbbadnak, azt ők is csak a szüleiktől tudják, és éppen azokkal a sorseseményekkel kapcsolatban van csekély - vagy semmilyen - hatásuk, amelyek saját életük eseményei: 1956, a disszidálások, a második gazdaság.

Több sorsesemény kapcsán is megszűnik a nagyszülők és unokák közötti folytonosság: a kitelepítések és a Rákosi rendszer más politikai megtorlásai egyaránt 5,5 százalékát nem érdekli az unokáknak, akár jelen vannak a nagyszülők az unokák életében, akár nincsenek, az 1956-os forradalom éppígy egyaránt 5,8 százalékukat nem érdekli, a hetvenes-nyolcvanas évek második gazdaságának családot érintő témáit pedig nagyobb arányban zárják ki életükből a fiatalok akkor, ha van, aki beszélhet róla a családban (8,0\%), mint akkor, ha nincsenek jelen nagyszülők $(7,1 \%)$.

Ez azért is figyelemre méltó eredmény, mert a nagyszülők és az unokák érzelmi kapcsolatát általában pozitívként írja le minden kutatás, és a szocializáció folyamatában betöltött szerepük az értékfolytonosság megerősítését hozza magával. A politikai szocializációval gyakran párhuzamba állított vallási szocializációt kutatva pl. Bengtson és szerzőtársai (2009) azt találták, hogy az Egyesült Államokban a fiatalok között a vallásosság megerősödésében annak az új családszociológiai jelenségnek van szerepe, hogy ismét gyakoribbá válnak a többgenerációs családok. Ezekben a családokban éppen a nagyszülőket azonosítják a vallási szocializáció megkülönböztetett tényezőiként. Úgy tűnik, hogy a magyar fiatalok politikai szocializációjában inkább fordított lehet a helyzet.

Nem kell feltétlenül a magyar és az amerikai generációk közötti érzelmi viszonyok különbözőségére gyanakodni - bár ez is egy magyarázat-lehetőség. Valószínúbbnek tartjuk, hogy a magyar nagyszülők maguk is csak arról tanultak meg beszélni, amiről nekik is beszéltek a felmenőik, a saját sorsukról azonban leginkább hallgatni kellett megtanulniuk, mivel „oly korban éltek $i t t^{\prime \prime}$. Ez a hipotézis természetesen már nem ellenőrizhető saját adatainkon, elemzéseink egyik eredményének, a további kutatásokra hagyott kérdésnek tekinthető.

A nagyszülők azonban - mint láttuk - csak a családok kisebb részében (46,5\%) vannak jelen, különösen az egy háztartásban élők között. ${ }^{23}$ Szülők viszont csaknem minden esetben jelen vannak. Ha a már vizsgált nagyszülők felől közelítjük meg a hatásukat, akkor az az első kérdés, hogy mi jellemzi a nagyszülők nélkül, csak szüleikkel élő gyerekeket körülvevő családi

\footnotetext{
${ }^{23}$ A kutatás koncepcióját tartalmazó közleményünkben már jeleztük, hogy a családi szocializáció kutatásában nem elég az együtt élőket tekinteni családnak, mivel a kommunikáció intenzív lehet a családmaggal nem együtt élő rokonnal - pl. nagyszülővel - is.
} 
emlékezetet, ennek változatosságát mennyire befolyásolja a szülők közötti kapcsolat zavara (válás, nevelőszülő belépése vagy az egyik szülő hiánya), azaz a család épsége.

Eddigi elemzéseinkből már tudjuk, hogy a gyerek által említett családi sorsesemények száma jó közelítést ad a családi emlékezet állapotáról. Ha most a család épségének (azaz az édes-szülők együttélésének) és a nagyszülőkkel való kapcsolat meglétének hatását ellenőrizzük, azt találjuk, hogy a család épsége semmiféle érdemleges hatással nincs a gyerekben továbbélő emlékek számára sem a nagyszülőkkel való kapcsolat hiánya, sem megléte esetén. A nagyszülőkkel való kapcsolat megléte mind az ép, mind a sérült családokban épp csak kívül esik a szignifikancia-határon (ami ekkora mintán igencsak gyengíti megállapításunkat), de konzekvensen különbözik a szülők hatásától: mindig bővíti a gyerekben továbbélő családi emlékezetet.

$$
\text { 10. táblázat: Hány családi sorseseményt említ? - átlag (szórás) }{ }^{24}
$$

\begin{tabular}{|l|c|c|}
\hline \multirow{2}{*}{$\begin{array}{l}\text { A család } \\
\text { állapota }\end{array}$} & \multicolumn{2}{|c|}{ Van-e nagyszülö-kapcsolat? } \\
\cline { 2 - 3 } & Van & Nincs \\
\hline Ép & $1,878(0,088)$ & $1,558(0,077)$ \\
\hline Sérült & $1,863(0,059)$ & $1,596(0,053)$ \\
\hline
\end{tabular}

A nagyszülők hatása szignifikánsan kimutatható, ha kihagyjuk az elemzésből szülőket, akik még interakciós hatást sem

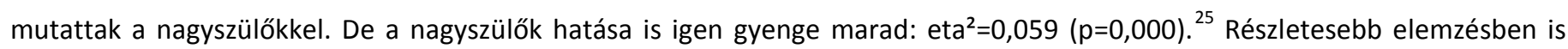
csak a nagyapa vagy a két nagyszülő együttes hatása volt kimutatható, az itt használt összevont változóban azonban a megözvegyült nagymamák is benne vannak, és az ő számuk jóval nagyobb, mint a nagyapáké. Ez tehát gyengíti a kimutatható kapcsolatot. Ezzel együtt el kell ismerni, hogy ez a hatás nem nagyon erős.

Azt nem logikus feltételezni, hogy a család gyerekeinek száma befolyásolhatná az emlékezetet, de általánosabban, a család nagysága - amit az együtt élő családtagok számával mérhetünk - lehetne rá hatással azon az alapon, hogy nagyobb családban nagyobb lehet a kommunikáció sűrüsége. A gyerekgeneráció emlékezetében élő családi sorsesemények száma és az együtt élők száma között azonban gyakorlatilag nincs korreláció ( $r=0,015 ; p=0,344)$, tehát a család nagysága nincs hatással az emlékezetre.

\section{A CSALÁDI KULTÚRA HATÁSA}

Az emlékezés kulturális jelenség. Várható, hogy ha a család szerkezeti típusa - pl. az együtt élő generációk száma révén sajátos keretet ad is neki eltérő személy-együttesek hatását téve lehetővé, sajátosságaiban az e személyek által hordozott kultúrától függ. Ezek legáltalánosabb szintű mutatója a szülők iskolázottsága. Bár kulturális összefüggésekben az anyák hatása szokott nagyobb lenni, láttuk, hogy a történelmi emlékezet fenntartásában az apáknak nagyobb szerep jut, mint az anyáknak, ezért elsősorban az apák iskolázottságát vesszük itt figyelembe - együtt a család épségével és a nagyszülők hatásával. (8. ábra)

\footnotetext{
${ }^{24}$ A varianciaelemzés szerint a nagyszülőkapcsolat hatásának valószínűsége csöpp híján $95 \%(p=0,058)$, a család épségének hatása nem valószínú $(p=0,739)$ és interakciós hatás sincs $(p=0,709)$.

${ }^{25}$ Egytényezős ANOVA.
} 
8. ábra

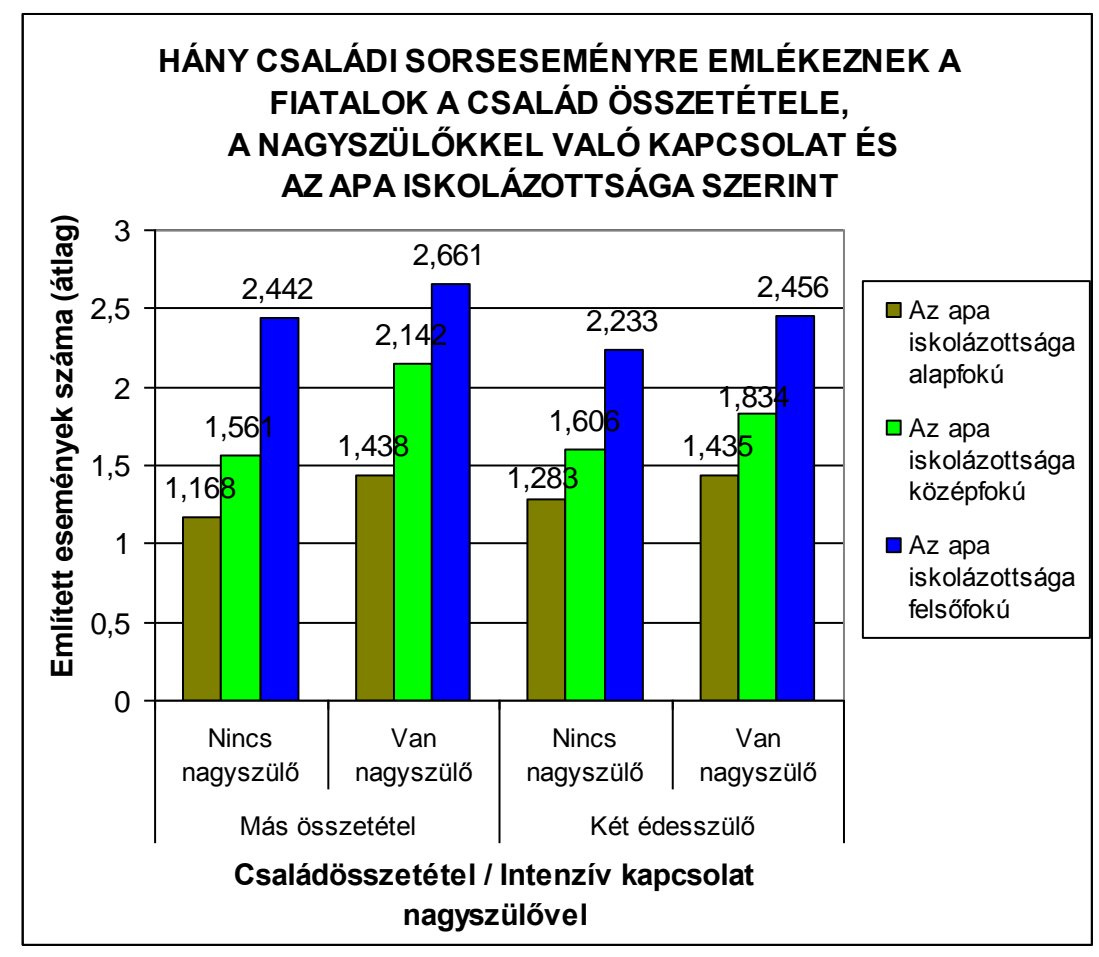

A több szempontú varianciaelemzés azt a meglepő eredményt hozta, hogy a három tényező közül - a család épsége, legalább egy nagyszülővel való intenzív kapcsolat és az apa iskolázottsága ${ }^{26}$ - egyedül az apa iskolázottságának van szignifikáns magyarázó ereje a gyerek által ismert családi sorsesemények számát illetően. Az 8. ábra négy oszlopkötege között nincs jelentős különbség, csak a kötegeken belül. Az talán mégis meglepő egy kicsit, hogy az átlagok a sérült családokban a legmagasabbak amennyiben a gyereknek van kapcsolata legalább egy nagyszülővel. Az ép családokban ennek az ellenkezője feltűnő: ha e családok gyerekeinek életében nincs jelen nagyszülő, akkor a leggyengébb a családi emlékezet. Bár ezek a különbségek nem bizonyultak szignifikánsnak, szintén arra a más adatokból már szignifikánsan megállapított tényre utalnak, hogy a szülőgeneráció már nem tekinthető a családi emlékezet fenntartójának, inkább megszakítóként múködik.

A család épségének figyelmen kívül hagyásával világossá válik, hogy az apa iskolázottsága és a nagyszülővel való kapcsolat hatása egyértelmü (9. ábra).

${ }^{26}$ A nyolc értékű nyers változóból háromértékű változót képeztünk, melynek értékei: alapfokú, középfokú és felsőfokú iskolázottság. Ehhez az a tény szolgál alapul, hogy a családi emlékezet klaszterei közül a hosszabb távú emlékezettel rendelkező klaszter aránya csak e három fok szerint különül el: az alapfokú végzettséggel rendelkező apák gyerekeinél 5 százalék alatt marad, a középfokú végzettséggel rendelkező apák gyerekeinél sem éri el a 10 százalékot, egyedül a diplomások gyerekeinél megy fel 10 és 15 százalék közé, miközben a teljes mintában 6,8 százalék az arány. Úgy túnik tehát, hogy érdemes feláldozni a finomabb bontást a nagyobb statisztikai elemezhetőség érdekében. 


\section{9. ábra}

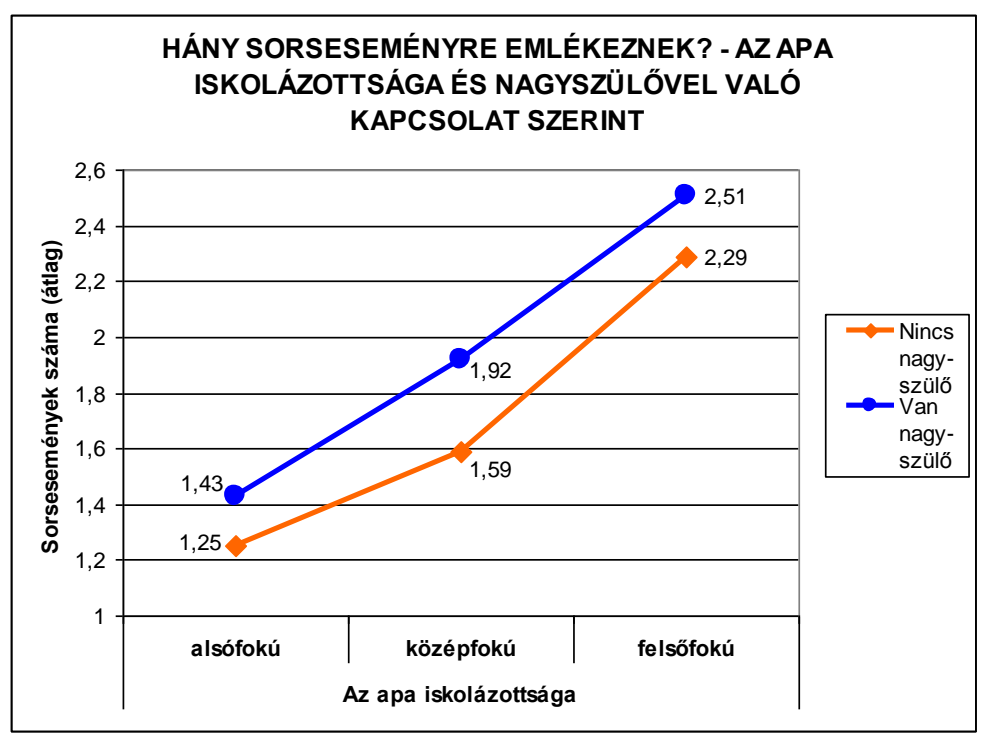

A nagyszülővel való kapcsolat megléte és hiánya közötti különbség független a családi kultúrától, és fordítva. Ezt az állításunkat azonban még pontosabban ellenőriznünk kell olyan származtatott változókkal, amelyek finomabban leírják a család kultúráját az apa iskolázottságánál.

Bár a foglalkozások és az iskolázottság között köztudottan szoros összefüggés van, sőt el sem választhatók teljesen egymástól, feltételezhetjük, hogy a foglalkozások kultúrája sajátos módon befolyásolja ezeket a folyamatokat. Az apa foglalkozási csoportjából és iskolázottságából aggregált változót képezve ${ }^{27}$ érdekes megfigyelést tehetünk (11. táblázat).

11. táblázat: A családi emlékezet-klaszterek eloszlása az apák néhány foglalkozási státus-kategóriájában

\begin{tabular}{|l|l|c|c|c|c|}
\hline \multicolumn{2}{|l}{ Az apa státusa } & \multicolumn{3}{c|}{ Családi emlékezet-klaszter } & \\
\hline Foglalkozási kategória & Iskolaszint & $\begin{array}{c}\text { alig emlékező } \\
\text { családok }\end{array}$ & $\begin{array}{c}\text { rövid távon } \\
\text { emlékezők }\end{array}$ & $\begin{array}{c}\text { hosszú távon } \\
\text { emlékezők }\end{array}$ & $\mathrm{N}$ \\
\hline Vállalkozók & max. középiskola & $60,0 \%$ & $34,8 \%$ & $5,3 \%$ & 417 \\
\hline & felsőfokú diploma & $44,5 \%$ & $45,4 \%$ & $10,1 \%$ & 346 \\
\hline Vezetók & max. középiskola & $55,6 \%$ & $38,4 \%$ & $6,1 \%$ & 99 \\
\hline & felsőfokú diploma & $46,7 \%$ & $41,2 \%$ & $12,0 \%$ & 274 \\
\hline Szellemi fogl. & max. középiskola & $50,6 \%$ & $41,6 \%$ & $7,8 \%$ & 77 \\
\hline & felsőfokú diploma & $47,9 \%$ & $39,7 \%$ & $12,3 \%$ & 317 \\
\hline Egyéb fizikai & alacsony isk. & $61,4 \%$ & $35,7 \%$ & $2,8 \%$ & 428 \\
\hline & min. középfok & $50,8 \%$ & $44,3 \%$ & $4,9 \%$ & 122 \\
\hline Gazdálkodó & & $42,6 \%$ & $44,4 \%$ & $13,0 \%$ & 54 \\
\hline Más mezőgazdasági & & $52,2 \%$ & $42,2 \%$ & $5,6 \%$ & 90 \\
\hline Fegyveres & alacsony isk. & $48,4 \%$ & $37,1 \%$ & $14,5 \%$ & 62 \\
\hline & min. középfok & $50,9 \%$ & $36,4 \%$ & $12,7 \%$ & 55 \\
\hline Besorolhatatlan & alacsony isk. & $67,5 \%$ & $29,6 \%$ & $2,9 \%$ & 379 \\
\hline ÖSSzMıNTA & & $55,2 \%$ & $38,1 \%$ & $6,7 \%$ & 3428 \\
\hline
\end{tabular}

\footnotetext{
${ }^{27}$ A család társadalmi státusának leírását külön fejezetben adjuk.
} 
Nemcsak az látható, amit már az iskolázottság hatásaként is megfigyeltünk. A foglalkozási csoportok befolyásolják az iskolázottság hatásának érvényesülését minden fehérgalléros kategóriában, amint a páronként egymást követő sorokból kitűnik: a magasabb végzettségűek családjai azonos foglalkozási csoporton belül is sokkal inkább őrzik a családi sorsesemények emlékét, mint az alacsonyabban iskolázottak. Az is látszik azonban, hogy van néhány foglalkozási kategória, amely az iskolázottságtól függetlenül „előnyös” a családi emlékezet fennmaradásához - ilyen a gazdálkodók csoportja és a fegyveres testületek. Mindkét kategóriában kevesebb a nem vagy alig emlékező család, és több a hosszabb távra emlékező - a gazdálkodóknál a rövidebb távra emlékező is - mint a minta egészében. Ennek magyarázatára csak külön-külön feltevéseket tudunk megfogalmazni. Elképzelhető, hogy a gazdálkodó családokban a családi kötődés még mindig erősebb, jobban őrződnek a hagyományok. A fegyveres testületek tagjai viszont talán a listánkon található háborúk és a forradalom emlékének őrzésével tűnnek ki - ez ellenőrizhető (10. ábra).

\section{0. ábra}

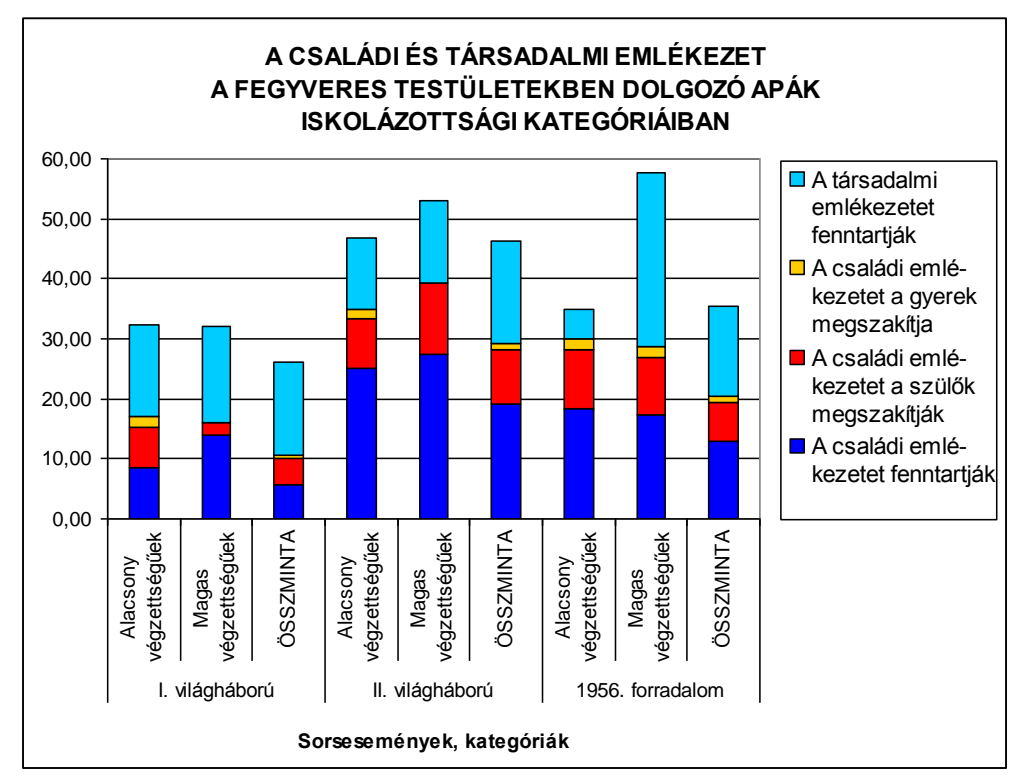

Az adatok igazolják sejtésünket, de azt is megmutatják, hogy a dolog nem magától értetődő, és a „harcos” sorsesemények mindegyike sajátos attitűdöt alakít ki. Az I. világháborút családi emlékként már csak a magasabb végzettségű fegyveresek családja őrzi jelentős arányban, az alacsonyabb végzettségűeknél már a szülők generációjában is jelentős az emlékezet megszakításának aránya. A II. világháború még minden családban élénkebben él, itt kevésbé tünik ki a fegyveres testületek azért kétségtelenül meglévő - előnye. 1956 emléke viszont egészen másképp él e foglalkozási csoport alacsonyabb és magasabb iskolázottságú kategóriáiban. A különbség itt nem a családi emlékezetben van, mint az I. világháború esetében, hanem a társadalmi emlékezetben. Úgy tûnik, mintha a társadalmi emlékezetet szinte teljesen kisajátítanák a testületek magasabban iskolázott tagjai. Hajlamosak vagyunk ebben annak jelét látni, hogy 1956 még aktív eleme mai politikai téteknek, amelyek érthetően erősebben érintik a magasabb beosztásúakat.

Ebből is látható, hogy nemcsak valamilyen általános „emlékező hajlam” erősebb vagy gyengébb működéséről van itt szó, hanem arról is, hogy bizonyos eseményekre egyes foglalkozási kategóriák - illetve a velük járó szervezeti nyomás és az általuk meghatározott kulturális élményközeg, amelyet a családok hordoznak - sokkal érzékenyebbek lehetnek másoknál. Érdemes ezért hasonlóképpen megvizsgálni a gazdálkodó apák családjainak érzékeny pontjait is. Kézenfekvő feltevés, hogy 
ezeket a mezőgazdasággal - vagy azzal is - kapcsolatos sorsesemények között keressük: a kulákok üldözése és a háztájizás lehet ilyen (11. ábra).

\section{1. ábra}

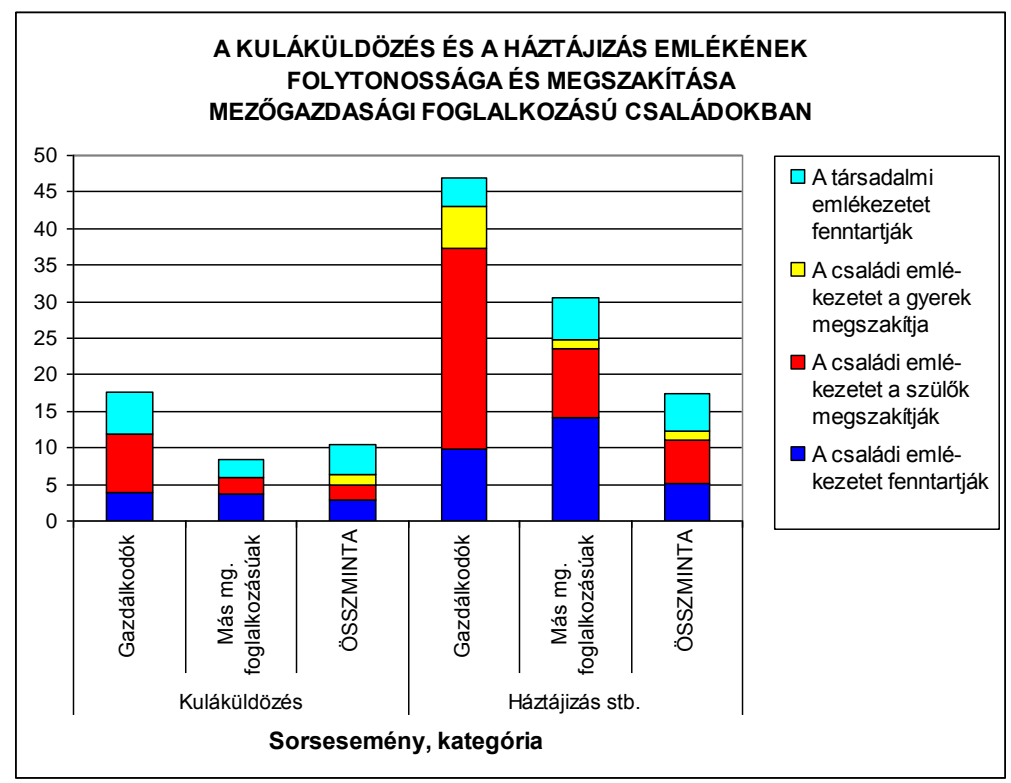

Kiderül, hogy a kulákok üldözésének emlékét alig őrzik nagyobb arányban a mezőgazdaságban dolgozó családok, mint a többiek; a társadalmi emlékezet is csak a gazdálkodók között gyakoribb az átlagosnál. A kuláküldözés sem családi sorseseményként, sem a társadalmi köztudat témájaként nem igazán élő, és már a szülők generációja - az elszenvedők gyerekei - is megszakították vagy épp most szakítják meg az emlékezés fonalát. Eléggé valószínű, hogy ez a tény az 1989-ig működő pártállami rendszer által gyakorolt politikai elfojtás eredménye. A háztájizás azonban a rendszer által támogatott népszerű gazdaságpolitikai elem volt, ez azonban csak a családi sorseseményként való fennmaradásán látszik meg, és a szülők generációja kiemelkedően nagy arányban munkálkodik az emlék kitörlésén - vagy úgy, hogy már nem is hajlandó róla beszélni, vagy úgy, hogy maga még beszél ugyan róla, de ezekből a beszélgetésekből a gyerekeit már kizárja. Ez a tendencia - meglepő módon különösen a gazdálkodók családjában erős. Itt a gyerekek nemzedékében is erős az érdektelenség a témával szemben. Az is feltűnő, hogy a többi mezőgazdaságban dolgozó családban viszont éppen a háztájizás családi emlékének fenntartása gyakoribb az átlagos aránynál. Ezek a tények egyrészt további megerősítést, másrészt magyarázatot igényelnek a következő kutatásoktól.

Mindezek alapján meg is fordíthatjuk kérdésünket. Eddig azt kérdeztük: megőrzik-e bizonyos sorsesemények emlékét a családok szerintünk erre hajlamos csoportjai? Most azt keressük: mely családok igyekeznek megőrizni bizonyos sorsesemények emlékét, és melyek szakítják meg ezt az emlékezetet? Olyan sorseseményekkel kapcsolatban vizsgáljuk ezt, amelyekről feltételezhető, hogy erősebb hatással lehetnek az új generáció politikai szocializációjára - pl. a kitelepítésekkel és egyéb politikai megtorlásokkal kapcsolatban. (12. táblázat) 
12. táblázat: A kitelepítések és egyéb politikai megtorlások emlékének megőrzése és megszakítása az apa foglalkozási státusának kategóriáiban (\%)*

\begin{tabular}{|c|c|c|c|c|c|}
\hline \multirow[b]{2}{*}{$\begin{array}{l}\text { Foglalkozási } \\
\text { csoport }\end{array}$} & \multirow[b]{2}{*}{$\begin{array}{l}\text { Képzettségi } \\
\text { szint }\end{array}$} & \multicolumn{3}{|c|}{ A családi emlékezetet } & \multirow{2}{*}{$\begin{array}{l}\text { A társadalmi } \\
\text { emlékezetet } \\
\text { fenntartják }\end{array}$} \\
\hline & & fenntartják & $\begin{array}{c}\text { a szülők } \\
\text { megszakítják }\end{array}$ & $\begin{array}{c}\text { a gyerek } \\
\text { megszakítja }\end{array}$ & \\
\hline \multirow[t]{2}{*}{ Vállalkozók } & max. középfok & 7,3 & 7,8 & 0,5 & 6,5 \\
\hline & diplomás & 14,9 & 10,5 & 0,6 & 6,8 \\
\hline \multirow[t]{2}{*}{ Vezetők } & max. középfok & 8,2 & 4,1 & 1,0 & 4,1 \\
\hline & diplomás & 10,8 & 8,5 & 0,8 & 11,5 \\
\hline Alsóvezető & diplomás & 8,0 & 3,4 & 1,1 & 12,6 \\
\hline \multirow[t]{2}{*}{ Szellemi } & alsófokú & 12,5 & 4,2 & 1,4 & 5,6 \\
\hline & felsőfokú & 12,0 & 13,6 & 3,3 & 9,0 \\
\hline Szakmunkás & max. középfok & 3,6 & 6,1 & 1,4 & 7,0 \\
\hline Más fizikai & max. középfok & 5,6 & 5,3 & 1,5 & 8,1 \\
\hline Fizikai m. & felsőfokú & 4,2 & 6,8 & 4,2 & 9,3 \\
\hline Gazdálkodó & & 7,8 & 13,8 & 2,0 & 3,9 \\
\hline Más mg. fogl. & & 6,0 & 9,5 & 0,0 & 7,1 \\
\hline \multirow[t]{2}{*}{ Fegyveres } & alsófokú & 3,3 & 13,3 & 3,3 & 15,0 \\
\hline & felsőfokú & 7,5 & 9,5 & 1,9 & 15,1 \\
\hline \multirow[t]{2}{*}{ Egyéb } & alsófokú & 5,1 & 3,4 & 0,8 & 6,8 \\
\hline & felsőfokú & 3,9 & 6,6 & 0,7 & 7,2 \\
\hline \multicolumn{2}{|l|}{ ÖSSZMINTA } & 7,6 & 7,5 & 1,3 & 7,9 \\
\hline
\end{tabular}

* Az emlékezet fenntartását leginkább mutató csoportokat vastag számokkal, az emlékezést leggyakrabban megszakítókat vastag dőlt számokkal jelöltük.

Az ötvenes évek politikai elnyomó intézkedéseinek családi emlékét leginkább a magasan iskolázott szellemi foglalkozású vezető és értelmiségi - kategóriákhoz tartozó családok őrzik és tartják fenn. Lehetne jelentést tulajdonítani annak a ténynek is, hogy ezek közül a legnagyobb arányban az érintett diplomás vállalkozók családjában téma ez, mégpedig úgy, hogy a család legfiatalabb generációját is bevonják az emlékező beszélgetésekbe. Feltételezhetjük, hogy a kitelepítés típusú intézkedéseket a családi emlékezetben megőrző és az új nemzedékre is továbbhagyományozó családok politikai orientációja is másképp alakul, mint azoké, amelyekben a szülők megszakítják ezt az emlékezetet. Durva közelítése lehet ennek a családoknak az őszödi beszédhez való viszonya, mivel az őszödi beszéd az adatfelvétel idején kormányzó párt által ébren tartott ellenségkép egyik fontos eleme volt, így azt várjuk, hogy azok a foglalkozási kategóriák, amelyek inkább őrzik az ötvenes évek politikai elnyomásának családi emlékét hajlamosabbak lesznek az őszödi beszédet is témáik között tartani, míg a kemény diktatúra családi emlékét megszakítók az őszödi beszéddel is ritkán foglalkoznak. A 12. ábrában csak azokat a foglalkozási kategóriákat szerepeltetjük, amelyek a 12. táblázatban pozitív vagy negatív irányban jelentős eltérést mutattak a többitől. 
12. ábra

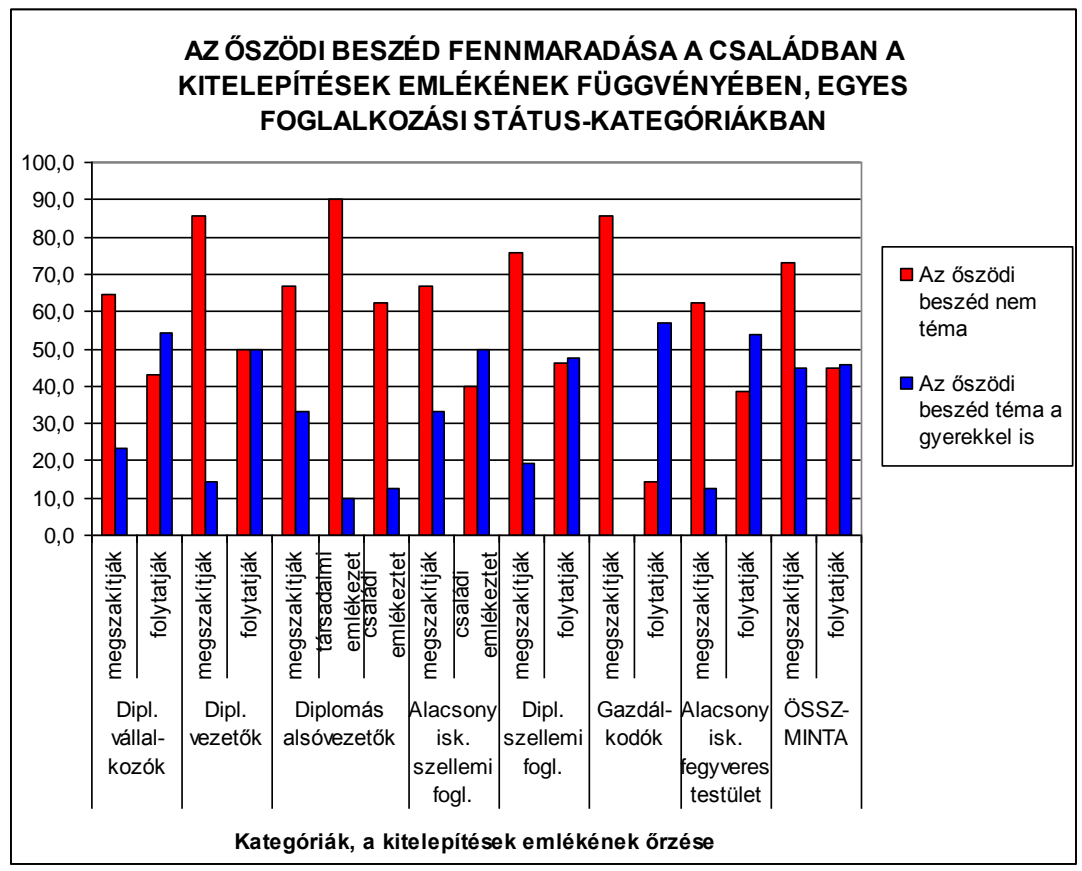

Az adatok tanúsága szerint az őszödi beszéd általában kevéssé került be a családi kommunikációba. Az azonban egyértelmű, hogy a régi meghurcoltatások emlékét őrző családokban - különösen a gazdálkodóknál - sokkal gyakrabban adódik hozzá a beszélgetések témáihoz, mint más miliőkben. Az érem másik oldala az, hogy ezeknek a családoknak is legfeljebb a felében lép fel ez a hatás, csak a már említett gazdálkodók, a fegyveres testületek alacsonyabb iskolázottságú tagjai, a diplomás vállalkozók és diplomás vezetők, valamint az alacsonyabb végzettségú szellemi foglalkozásúak családjaiban haladja meg vagy éri el az 50 százalékot.

Ez összefoglalva azt jelenti, hogy az emlékezés témái még ilyen esetben is kevésbé tartósak, mint gondolnánk: a családi emlékezet különböző időtartamig őrzött sorsesemények folytonosan változó fonadékaként és folyamaként létezik, amelyet feltehetőleg sokkal lassabban változó családi értékek tartanak mederben. Ez az állandó és elég gyors változás teszi nehézzé a politikai szocializáció folyamatának kutatását, és ez is arra vezet, hogy e kutatásoknak jelentős részben az értékekre kell irányulniuk. Az értékek szempontjából ebben a konkrét esetben azt gyaníthatjuk, hogy az ötvenes évek jogsértéseinek emlékét az őszödi beszéddel együtt tematizáló családok feltehetően ma erős jobboldali értékeket ápolnak, és ebből a szempontból a felsorolt kategóriák inkább megosztottak, csak a gazdálkodók látszanak határozottnak.

\section{A CSALÁDTAGOK POLITIKAI AKTIVITÁSÁNAK ÖSSZEFÜGGÉSE AZ EMLÉKEZETTEL}

Láttuk, hogy három sorsesemény azzal tűnt ki a többi közül, hogy a családi emlék elhomályosulta vagy hiánya ellenére erősen fennmarad, és a családi beszélgetések fenntartják mint társadalmi emlékezetet (6. ábra). Az I. világháború, Trianon és a holokauszt mutatkozott ilyennek. Ezek tűnnek a legalkalmasabbnak annak vizsgálatára, hogy személy szerint kik is az emlékezet hordozói. Konkrétabban: vajon a családtagok politikai aktivitása erősíti-e az emlékezetet?

A válasz egyértelmű igen (13. ábra). Az érintettség tudatát - vagyis az emlékezés egyre ritkább, tehát értékesebb fajtáját - a rendszerváltás előtt ellenzéki tevékenységben részt vevő szülők és rokonok kiemelkedő aránya jellemzi. 


\section{3. ábra}

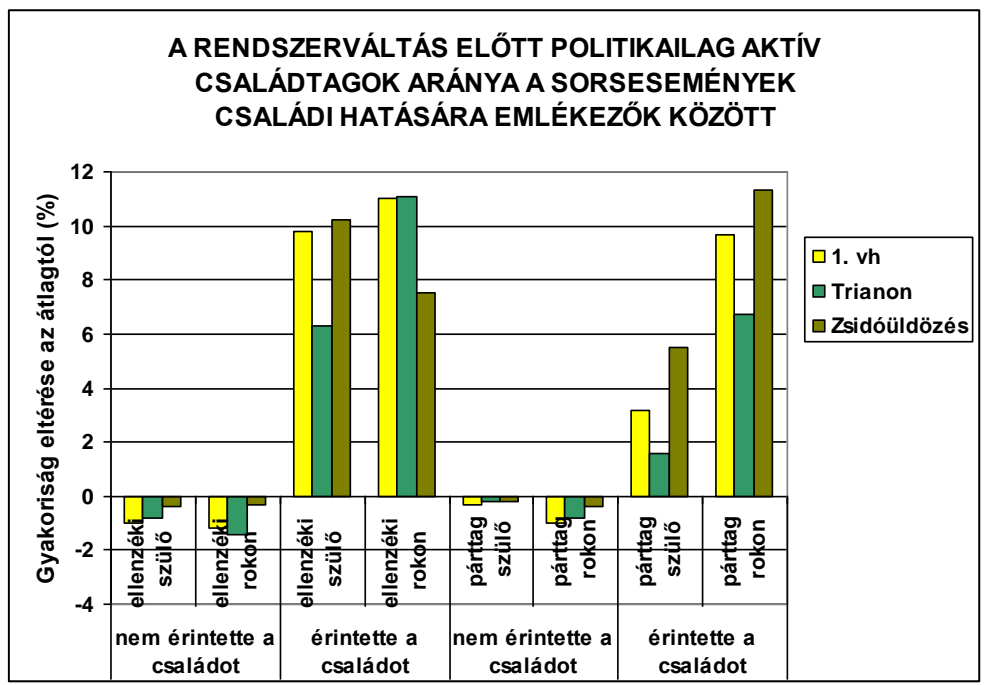

Két dolog feltűnő ezen belül:

1) Az érintettség emlékét továbbadók között feltűnően nagy szerepük van a rokonoknak, még nagyobb, mint a szülőknek.

2) Az emlékezés fenntartását a politikai aktivitás mindenképpen segíti, függetlenül annak orientációjától: az ellenzéki és a párttag családtagok egyaránt nagy arányban vannak. Igaz, a párttag szülők számítanak a legkevésbé, de ez adódhat abból a sajátos, szinte semmire sem kötelező viszonyból, amit a párttagság a szülők nemzedékének életében jelentett. Ne felejtsük el, hogy legtöbbjük a nyolcvanas évek közepén érte el azt az életkort, amelyben egyáltalán párttag lehetett, ők tehát már egy „fellazított” pártba léptek be. Ez a jelentéktelenség ugyan érvényes lehetett a párttag rokonok nagy részére is, őket azonban éppen az emeli ki a szürkeségből, hogy az általunk később megkérdezett gyerek számára megkülönböztetetté váltak - talán hajlamosak voltak olyan témákról is beszélgetni vele, amelyekről a szülők ritkán vagy alig szóltak. Tudjuk, hogy a ritka vendég nem feltétlenül jelentéktelen, épp ritkasága miatt is lehet jelentős.

Természetesen csak alacsony létszámú csoportokról van itt szó. A rendszerváltás előtt ellenzéki tevékenységben - a válaszoló gyerek szerint - részt vett szülők aránya 3,8\%, a párttagoké 1,9\%. Ugyanezek az arányok a rokonságban: 8,7\% és 7,2\%. Ez azt jelenti, hogy a felserdült csemeték szerint szüleik között több volt az „ellenálló”, mint a párttag. Ez az adat részben az "óvatos feledékenység” eredménye is lehet, ha tudjuk, hogy a MSZMP egy időre már a hetvenes években létszámstoppot vezetett be, de létszáma 1986 végén kis híján elérte a 900 ezer főt. ${ }^{28}$ Az ellenzékiség köre még az egyszerű szamizdat-olvasókat beszámítva is több nagyságrenddel kisebb volt ennél. A statisztikába nem foglalható diffúz ellenérzés mértéke természetesen lehetett nagyobb, de azt nem számítanánk az ellenzéki tevékenység kategóriájába.

A kép tehát, amelyet kapunk, nem a számszerű valóság, hanem a vizsgált generáció tudatában élő kép. Abban viszont nemcsak a kiemelt esetekben mutatkozik az összefüggés, amelyet megállapítottunk. A politikailag érzékenyebb eseményeknél ugyanezt tapasztaljuk. Tekintsük meg ebből a szempontból a kuláküldözések, a kitelepítések és 1956 emlékét (14. ábra).

${ }^{28}$ „Az MSZMP taglétszáma 1957 és 1971 között évente 4-5\%-kal emelkedett, 1972 után a növekedés üteme a felvétel korlátozására hozott intézkedések következtében csökkent. Majd a gazdasági problémák megjelenésének időszakában, 1980-tól ugyan még tovább mérséklödött, de a növekedés 1987-ig így is folyamatos volt, ennek köszönhetöen a párt létszáma 1986. december 31-re elérte a csúcsot, a 883131 föt." (Réfi Attila: Tények és adatok a tagkönyvcsere tapasztalatairól, Népszabadság, 1988. szeptember 28.) 
Talán meglepő, hogy nem a forradalom emlékénél a legnagyobb a családtagok szerepe, hanem messze kiemelkedően a kuláküldözéseknél. Ennek értelmezése ugyan nagyon bonyolult lehet, de az a tanulság azért szembeötlő, hogy a pozitív politikai érintettség (párttagság) nem fojtja el az emléket, legföljebb kissé kevésbé segíti fennmaradását. Hatása akkor is pozitív, ha gyengébb.

14. ábra

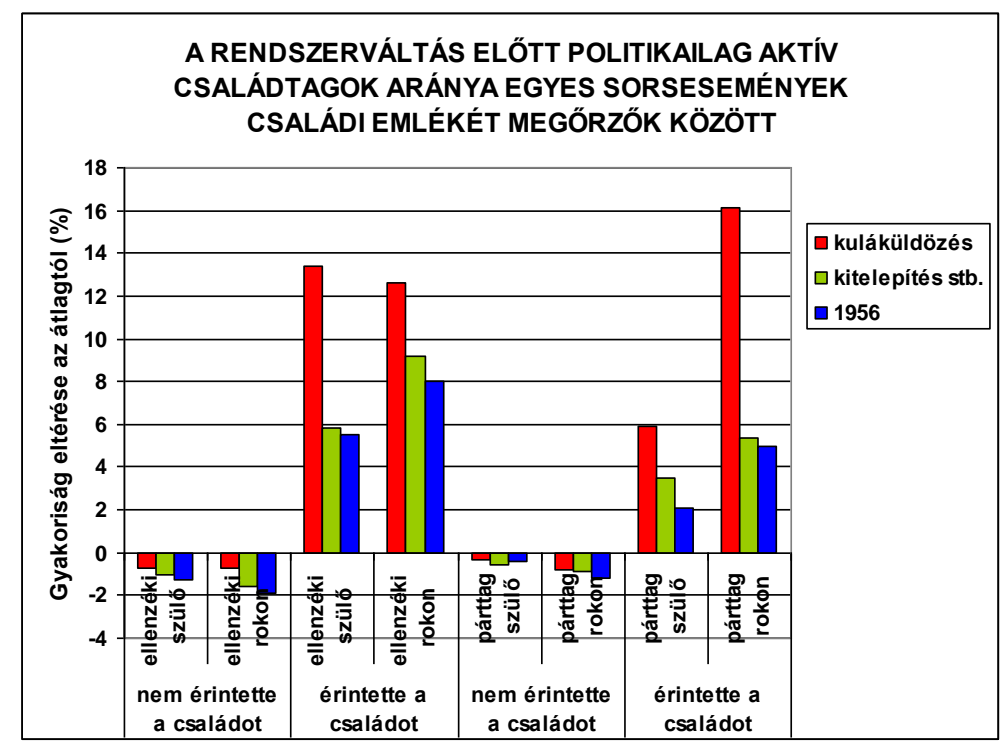

A politikailag nagyon érzékeny témákkal kapcsolatban ugyanazt állapíthatjuk meg: amelyik családban a gyerek úgy tudja, hogy ezek a sorsesemények érintették a családot, ott a politikailag bármilyen irányban involvált szülők és rokonok szerepe kiemelkedő. Ezen belül ismét a párttag szülők a legkevésbé jelentősek. Különösen 1956-tal kapcsolatban feltűnő ez. Mindössze 2 százalékos többletük bizonyára azért ilyen alacsony, mert ők felelősek a gyermek biztonságáért egy olyan világban, amelyben 1956 a két végső tabu egyike. ${ }^{29}$ A párttag rokonok nem viselnek ilyen közvetlen felelősséget, tehát nagyobb arányban tematizálhatják 1956-ot a gyerek előtt is. Ezt a hipotézist természetesen nem tudjuk ellenőrizni a jelen vizsgálat keretében. A 14. ábrában látható arányok azonban feltevésünk szerint leginkább a témák korábbi politikai „veszélyessége” szerint alakulnak.

\section{ÖSSZEGZÉS}

Elemzésünk azzal a tanulsággal zárul, hogy a családi sorsesemények verbális emlékezete Magyarországon általánosságban nem jelentős tényező a fiatal nemzedék családi politikai szocializációjában. A családok szűkebb körében érvényesülnek csak a feltételezett longuedurée hatások. Érvényesülésüket legjobban a szülők iskolázottsága és a tágabb család (rokonok) politikai aktivitása segíti elő, kisebb mértékben hozzájárul a nagyszülők - különösen a nagyapák - kapcsolata unokáikkal. Mivel az emlékezés megszakadása az esetek jelentős részében nem is a szülők, hanem már a nagyszülők generációjában vagy még korábban megtörtént, úgy tekintjük, hogy a legfőbb ellenerőt maguk azok a történelmi politikai viszonyok képezték, amelyek tartósan akadályozták a velük kapcsolatos emlékek meggyökerezését.

\footnotetext{
${ }^{29}$ Szabó Ildikó megfogalmazása szerint: „,az átpolitizált társadalmi gyakorlatból következett, hogy mindenkinek egzisztenciális érdeke füződött ahhoz, hogy a megfelelés látszatát keltse". (Szabó, én. [1991]:32)
} 
Ha nemcsak a verbális, hanem a tárgyi emlékezés elemeit is figyelembe vesszük, kitűnik, hogy a legerősebb tényező, amely a generációk közötti átvitelt elősegíti, a vallásosság. Ez azonban nem jelenti azt, hogy bármiben egy az egyhez megfelelést találhatunk a szülők és gyerekeik között. A fiatal nemzedék politikailag érintett kisebbségénél - amelyről egyáltalán beszélhetünk ebben a vonatkozásban - a szülők vallásos-történelmi kultúrájától némileg eltérő történelmi-politikai jellegű kultúra tűnik elő, mely hajlamos elkülönülni a vallásos elemektől. De a fiatalok tárgyi szimbólumainak világát sem a politika vagy a történelem, hanem a bulvár-kultúra uralja.

A családi emlékezet nem várt gyengesége és az emlékező kisebbségben tapasztalt tényezők miatt úgy véljük, hogy a serdülők politikai szocializációjában nagyobb jelentőséget kapnak a kortárs-kapcsolatok, a tágabb család, és a diffúz társadalmi közeg - pl. nem-politikai szervezetek, média - hatásai. Ezek elemzésére jelen kutatás kevéssé ad módot, de fontosnak tartjuk kutatásukat más keretekben.

IRODALOM

Andor M. (1999) A könyv mint a kulturális tőke mutatója. Iskolakultúra, 1999/11, 62-70.

Bengtson, Vern L. - Copen, Casey E. - Putney, Norela M. - Silverstein, Merril (2009) A longitudinal study of the intergenerational transmission of religion. International sociology. Vol. 24. Nr. 3 (May 2009) 325-345.

Berger, P. - Luckmann, Th. (1967) The social construction of reality. A treatise in the sociology of knowledge. Harmondsworth, Middlesex: Penguin Books Ltd.

Braudel, F. (1958) Histoire et sciences sociales : la longue durée.Annales. Économies, sociétés, civilisations. Vol. 13, no. 4, 725-753.

Csákó M. - Murányi I. - Sik D. - Szabó I. (2010) A családi politikai szocializációról. Társadalomkutatás, 28. köt. 4. sz. 419-446.

Easton, D. - Hess, Robert D. Hess (1962) The Child's Political World. Midwest Journal of Political Science.Vol. VI., No. 3 (August) $229-246$.

Jennings, M. K. - Niemi, R. G. (1981) Generations and Politics. A Panel Study of Young Adults and their Parents. Princeton, N. J.: Princeton University Press.

Jennings, M. K. - Percheron, A (1981) Political continuities in French Families: a new perspective on an old controversy. Comparative Politics 4. 421-436.

Melich, A. (1979) Comment devient-onsuisse? Enfants et apprentissagepolitique, Institut de Science Politique. Lausanne (Mémoire et documents, 11).

Percheron, Annick (1999) Az egyén politikai formálódása. In Szabó Ildikó - Csákó Mihály (szerk.) A politikai szocializáció. Válogatás a francia nyelvterület szakirodalmából. Budapest: Új Mandátum 18-43.

Reiss, D. (1981) The family's construction of reality. Cambridge, Mass: Harvard University Press.

Renshon, S. A. (1975) Personality and Family Dynamics in the Political Socialization Process. American Journal of Political Science. Vol. 19, No. 1 (Feb.) 63-80.

Szabó Ildikó (é.n.) (1991) Az ember államosítása. Politika szocializáció Magyarországon, Tekintet Alapítvány, hn. (Tekintet könyvek). 